BULLETIN OF THE GEOLOGICAL SOCIETY OF AMERICA

VOL. 30, PP. 499-566 DECEMBER 30, 1919

PROCEEDINGS OF THE PALEONTOLOGICAL SOCIETY

\title{
EVOLUTION OF GEOLOGIC CLIMATES ${ }^{1}$
}

BY F. H. KNOWLTON

(Read before the Paleontological Society December 28, 1918)

CONTENTS

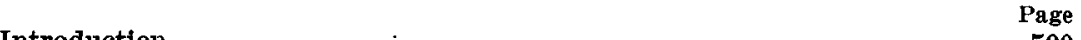

Introduction.................................. 500

Part I. Paleobotanical evidence in the interpretation of geologic climates. 501

Temperature toleration in plants and animals...............501

Paleobotanical criteria for determination of climatic conditions.... 503

Evidence of the floras............................. 506

Algonkian flora $\ldots \ldots \ldots \ldots \ldots \ldots \ldots \ldots \ldots \ldots \ldots \ldots \ldots \ldots, \ldots \ldots 6$

Cambrian and Ordovician floras................... 507

Silurian floras................................ 507

Devonian floras............................ 507

Carboniferous floras........................ 510

In general................... 510

Mississippian floras......................... 510

Pennsylvanian floras......................... $\mathbf{5 1 1}$

Permian flora and its climatic significance........... 514

Triassic floras.............................. 515

Late Triassic and early Jurassic time...............516

Jurassic floras...............................517

Cretaceous floras.............................. 520

Lower Cretaceous......................... 520

Upper Cretaceous.......................... 524

Climate of Upper Cretaceous time............... 525

Tertiary floras............................. 528

Origin of herbaceous types of vegetation............ 528

Eocene floras and their probable climatic requirements..... 529

Miocene floras and their climatic requirements......... 534

Pliocene floras and their climatic requirements........536

Part II. Origin and differentiation of geologic climate........... 537

Early climates non-zonal......................... 537

Consideration of the atmosphere...................... 539

Power of clouds in reflecting the sun's rays............... 540

1 Manuscript received by the Secretary of the Society August 23, 1919.

Published with the permission of the Director of the U. S. Geological Survey.

Entered on the printed program as "Climates of the past." 


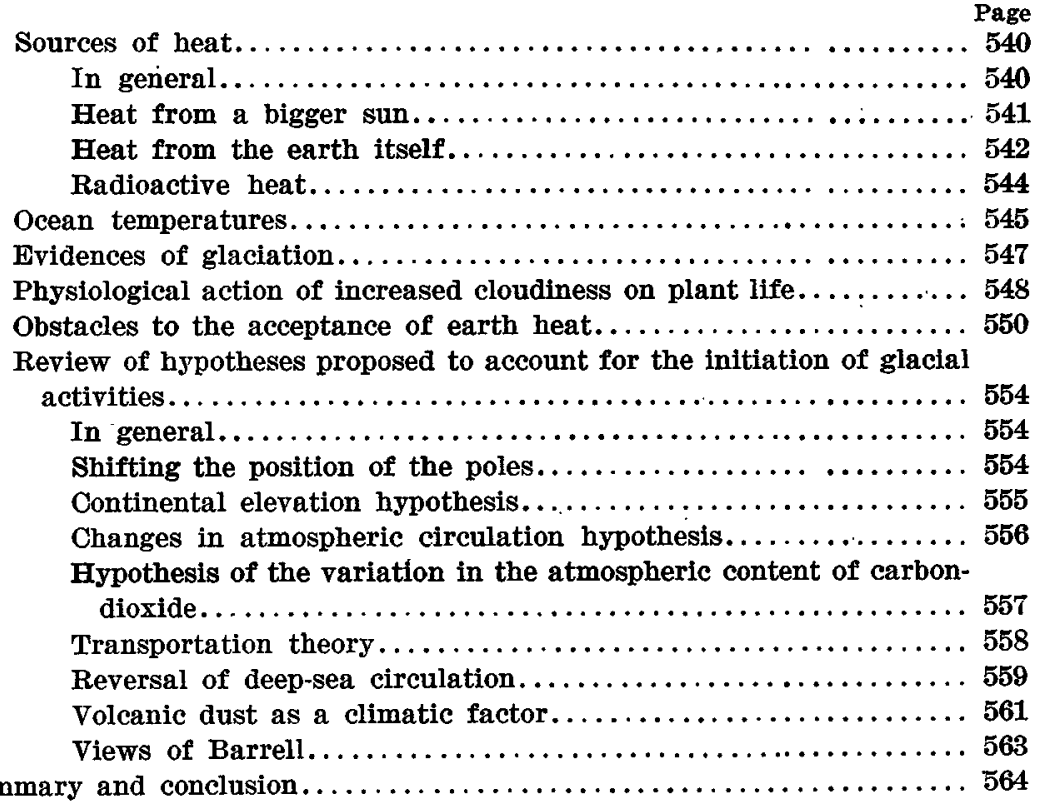

\section{INTRODUCTION}

In present-day acceptance the term climate has come to be applied to the atmospheric conditions or weather normal to a given locality or region, especially as affecting life, health, comfort, and the multifarious activities of terrestrial existence. Although there are very considerable areas of the earth's surface that exhibit similar climatic conditions, it needs little reflection to demonstrate that the climate of the earth is by no means uniform throughout. If, for instance, we travel either north or south from the equator, we pass successively through a so-called torrid zone, a temperate zone, and, in polar lands, a frigid zone, each with minor but distinctive modifications. In other words, the present distribution of climate is zonal.

This zonal distribution of climate on the earth, as we know it at the present time, is a phenomenon that appears to have had its origin, or at least its most marked accentuation, during and subsequent to the Pleistocene or so-called Ice Age. Its persistence at the present time is due to the very good reason that we are living in what is either an interglacial cycle, of which there already have been several, or possibly in a period that may represent the nermanent waning of the Ice Age. Although as 
familiar and as seemingly permanent as this climatic zoning is at the present time, it is believed that it can be conclusively demonstrated that it is more or less abnormal or exceptional--that is, when earth history is viewed as a whole it is increasingly evident that the time during which climate has been distributed in zones represents but a small fraction of geologic time.

The following may be taken as the thesis of the first part of this paper.

Relative uniformity, mildness, and comparative equability of climate, accompanied by high humidity, have prevailed over the greater part of the earth, extending to, or into, polar circles, during the greater part of geologic time--since, at least, the Middle Paleozoic. This is the regular, the ordinary, the normal condition. ${ }^{2}$

The study of climatic conditions that obtained during the past-the study of fossil climates, so to speak-is beset with some difficulties. Naturally, these conditions can only be interpreted through the impress retained by the physical and biological surroundings, and these are not always of equal distinctness or equal value. It is not the intention in the present paper to consider fully the purely geologic criteria; nor is it the intention, or indeed the desire, to draw any invidious comparisons between the two great classes of biologic criteria, but it is, I believe, generally admitted that plants inherently possess the qualities which permit them to exhibit the more reliable criteria as to the climatic conditions under which they passed through their life processes. A great majority of animals are endowed at some stage in their life cycle with the power of locomotion, which enables them to move about more or less freely in response to various external forces, perhaps the most important of which is that of the climatic environment. When, for whatever reason, the conditions become unfarorable, the animal is more or less free to change its habitat; but with the plant it is usually quite different.

\section{Part I. Paleobotanical Evidence in the Interpretation of geologic Climates}

\section{TEMPERATURE TOLERATION IN PLANTS AND ANIMALS}

Before presenting the paleobotanical evidence regarding ancient climates, it is pertinent to call attention to the fact that, whatever the decision may be regarding geologic climates, it is certain that since at least Algonkian time terrestrial temperatures have been stabilized be-

${ }^{2}$ David White and F. H. Knowlton: Science, new ser., vol. 31, 1910, p. 760. 


\section{2}

tween relatively narrow limits, else life could not have been continuous, as we have every reason to believe it has been. "The control of secular climates," says Professor Chamberlin, "is obviously a condition prerequisite to biologic continuity. The preservation of a narrow range of temperature and a limited variation of atmospheric constituents throughout the millions of years of the biologic past was absolutely essential to organic evolution. Continued preservation for millions of years to come seems equally a condition precedent to an intellectual and spiritual evolution commensurate with the physical and biological evolutions that have preceded it."

The vital processes in plants are practically suspended when the temperature falls below $32^{\circ}$ F. (O. C.), though during their resting stage many plants, especially in polar lands, are accustomed to endure a temperature of $-70^{\circ} \mathrm{F}$. or even lower. The opposite extreme is shown by certain simple types of algæ that thrive in the waters of hot springs under a temperature approximating $200^{\circ} \mathrm{F}$., and there is very considerable diversity of algal life in thermal springs with temperatures ranging between $140^{\circ} \mathrm{F}$. and $180^{\circ} \mathrm{F}$.

It is now known that certain bacteria and protozoa when in an encysted or resting stage can successfully endure a temperature of nearly $-200^{\circ}$ C. for six months and about $-250^{\circ} \mathrm{C}$. for shorter periods, and the spores of certain other bacteria can withstand for a shorter time a temperature as high as $120^{\circ} \mathrm{C}$. These extremes of tolerance, however, are far greater than the organism could endure when in active growth.

The optimum temperature for plant life is usually between $22^{\circ}$ and $37^{\circ} \mathrm{C}$. ( $71^{\circ}$ and $98^{\circ} \mathrm{F}$.). There is, however, quite a wide range for species and even different individuals of the same species. "In tropical plants the minimum temperature may be as high as $+10^{\circ} \mathrm{C}$., while those of higher latitudes, where the first plants of spring often grow through a covering of snow, as well as those of the higher Alps and polar regions, grow vigorously at a temperature but little above zero."-Strasburger.

The extremes of temperature between which animal life is possible are apparently less than for plants. For instance, no known animal finds a congenial habitat, either aquatic or terrestrial, that has a permanent temperature of $200^{\circ} \mathrm{F}$., though many of them can and do carry on their essential life processes at a temperature considerably below $32^{\circ} \mathrm{F}$., yet were such temperature to be reached they must ultimately succumb, since in its last analysis "all food of all animals is supplied by plants."

From the foregoing discussion it appears that the range of biologic

a T. C. Chamberlin : Jour. Geology, vol. 14, 1906, p. 363. 
toleration must be less than $200^{\circ}$ F.- - that is to say, a permanent raising of terrestrial temperatures above $200^{\circ} \mathrm{F}$., or a lowering below $32^{\circ} \mathrm{F}$., would have inhibited life on this globe. It is of course possible that life forms were more tolerant of temperature range in the earlier geologic ages, but from what is now known of the nature and demands of protoplasm this seems very unlikely.

\section{PALEOBOTANIOAL ORITERIA FOR DETERMINATION OF OLIMATIO OONDITIONS}

During the slightly more than one hundred years that practically cover the period of the scientific study of paleobotany, a vast body of facts has naturally been accumulated regarding the regetation of the past. The imperfection of the paleontologic record of course still leaves many lamentable gaps in our knowledge, though many of these are gradually being filled in. At the same time the study of the living floras, by which and through which the ancient floras must in large measure be interpreted, has also progressed by leaps and bounds. Through keenly prosecuted systematic studies the floras of the world have been made known to us, while through the newly developed study of ecology we have come to know much of the physical and environmental requirements of these floras. To this must also be added a greatly increased knowledge of histological and structural details, as well as marked advance in embryological, developmental, and evolutionary knowledge. Each of these factors is, to a great or less extent, now available in interpreting the floras of the past.

In seeking to ascertain the bearing of the floras on the climatic conditions that obtained at the time they were living, it is desirable to set forth the criterin that must form the basis of such judgment, and which it is believed will furnish the most reliable evidence. As I have stated on a former occasion :

"In drawing conclusions from individual organisms in an inquiry of this kind, dependence must of course be placed on our knowledge of the presentday requirements of similar species, and the results must always be subject to possibility of error from two sources-first, from the incorrect placing biologically of the organism, and, second, from the fact that its requirements in past geologic time may not have been the same as those which now dominate the life activities of its supposed analogue. However, when all the elements of a flora appear to point in the same direction the liability to serious error is minimized, if not eliminated."

In the present connection the criteria that may seemingly be relied on to furnish a reliable interpretation of climatic conditions have been so succinctly enunciated by White in his paper on the Origin of coal that I 


\section{4}

venture to quote it entire. Although it was drawn up especially to cover the conditions during the deposition of the great coal deposits, and more particularly the Paleozoic coals, it nevertheless applies with equal force to all horizons. White ${ }^{4}$ writes as follows :

"During the times of deposition of most of the principal coal groups the climate has been characterized by (1) general mildness of temperature, approaching in most cases tropical or subtropical ; (2) conspicuous equability or approximation to uniformity of climatic conditions, which, with a few exceptions, appear to have lacked cold winters or severe frosts; (3) a generally high humidity, the rainfall being from moderately heavy to very heavy and fairly well distributed through the year, though in many cases there is evidence of the occurrence of dry periods, which, however, seem ordinarily to have been comparatively short and not severe; (4) an amazingly wide geographical distribution of these genial and equable climates, which occurred seemingly in almost uniform development simultaneously in the high and in the low latitudes of both the Northern and the Southern Hemispheres. This shows either that the essentially uniform climatic conditions were truly extraordinary in geographic extent, with little regard to modern climatic zones, or that the formation of coal was mainly confined to the areas of the aboveprescribed climatic environment.

"The principal criteria as to climate offered by the fossil plant remains preserved either in the coal or in the enveloping shales and sandstones and, serving as a basis for the conclusions stated above, may be summarized as follows:

"1. Relative abundance or luxuriance and large size of terrestrial vegetation-that is, rankness of growth-indicating favorable conditions of temperature, humidity, etc.

"2. Character, condition, and amount of the land-plant material preserved as coal or carbonized in the rocks. The formation of xyloid coal of the ordinary types, composed mainly of subaerial vascular plant remains, indicates humidity. In regions of cool temperature the humidity required for the formation of peat-the initial state of coal-is moderate; in warmer climates, where decay is more rapid, not only must the humidity be greatly increased in order to provide the necessary wetness to retard decomposition, but there must be no long dry season of the year for the too great reduction of the water cover. The observations of peat formation at the present day in tropical climates show that in order to permit the deposition of peat the rainfall must be both very heary and fairly well distributed through the entire year.

"3. Great radial distribution, seemingly over the greater part of the earth, and especially over wide ranges of latitude, of identical species and genera in characteristic association, indicating the extension of approximately uniform climatic conditions in these regions. Floras identical, or essentially identical, in remote or detached regions can owe their identity to no other cause than approximate continuity of the environment, whether that continuity is geographic or chronographic. Conversely, migration of a flora without change is possible only through regions of essentially identical environmental conditions. Illustrations are found in the Carboniferous; Triassic, Jurassic, and Lower

4 David White: The origin of coal. U. S. Bureau of Mines, Bull. 38, 1913, p. 67. 
Cretaceous floras, and even to a remarkable degree in the Upper Cretaceous and Tertiary floras.

"4. Presence of types known to be adapted to or confined to the warm temperatures or moist climatic conditions of the present day, types that though now extinct once lived in association with other types of ascertained tropical or humid habitats, and types whose descendants or nearest surviving relatives are characteristic of warm climates. Examples are cycadalean types in Carboniferous, Triassic, Jurassic, Cretaceous, and, finally, in the Oligocene, in association, since the Trias, with living tropical and subtropical genera or families; the presence of tree ferns in nearly all periods of coal formation; palms, cinnamon trees, climbing ferns, and many other tropical or subrtopical types in the Upper Cretaceous; and bread-fruit trees, etc., in the Lower Tertiary.

"5. Structures of the plants themselves. Features showing rapidity of growth-that is, abundant rainfall, mild or warm temperatures, etc.-conditions favorable to rapid growth:

" $(a)$ Very large size of the cells, many with thin walls, and large intercellular spaces, indicating rapid growth and abundant moisture, noticeable in the woods found in and with most coal.

“(b) Large size of fronds and leaves, indicating conditions favorable to growth and, at present, characteristic of moist tropical habitats.

“(c) Frequency of laciniate or much-dissected, drooping fronds and pendent branches or twigs seemingly adapted to facilitate the run-off of rain, and protection of the stomata in grooves on the under sides of many leaves, as in the Lepidophytes of the Carboniferous.

"(d) Smoothness of bark, which is often thick, pointing toward warm humid swamps.

" $(e)$ Absence of growth rings in the woods of the older coal formations, showing climatic conditions favorable to practically uninterrupted growth, and the absence of long dry seasons or winter frost. Such absence of rings, when noted in all the associated types, plainly shows the approximation to equability of climate.

" $(f)$ Wide occurrence in the Paleozoic coal fields of heterospory, requiring prevalent swamp conditions; and the occurrence of delayed fertilization and of devices for seed flotation.

" $(g)$ The development of subaerial roots in many of the types.

"6. A circumstance that may be observed in most coal fields in proof of abundant rainfall at the time of coal formation is the continuity of many coal benches or strata from one hollow or pan over the intervening shoal or sand bar into the next pan or along the slight gradients of the base levels, a circumstance impossible except with sufficient rainfall to saturate the vegetal cover and maintain a ground-water table of retarded drainage held by the obstructing vegetation.

"7. Two other interesting lines of evidence for the warm climate of the Carboniferous are seen, as pointed out by Potonie, in $(a)$ the development of more flowers and fruits on the lower parts of stems and branches, as in Ulodendron, Sigillaria, and many Calamarix, a characteristic of dense tropical forests at the present time, and $(b)$ the presence in many ferns of Aphlebir, which today are unknown except in tropical types." 


\section{EVIDENCE OF THE FLORAS}

Algonkian flora.-So far as how known, the first plants of which we have a definite record occur in the Algonkian formations of the Cordilleran area of western America. From these beds, which are more than 5,000 feet thick and fully 6,000 feet below the overlying Cambrian, Mr. Walcott ${ }^{5}$ has described 6 genera and 10 species of organisms that had the power of secreting and depositing calcium and magnesium carbonate. They appear to be algæ closely allied to the Cyanophyceæ, or blue-green algæ, and are believed to have been largely instrumental in depositing the great pre-Cambrian limestones of western America. The waters in which these algæ lived are thought to have been fresh.

These organisms are so obscure and still so little understood that it is hazardous to venture an opinion as to the temperature conditions under which they might have lived. Walcott makes the following observations as to the climate of the time:

"The presence of great thicknesses of red sandstones and shales in the Algonkian sections of the Grand Canyon and Belt series of Montana suggests an arid, possibly a cold, climate. Opposed to this are the great limestone beds which indicate a fair supply of water to form inland seas whose temperature was sufficiently high to permit of an adequate growth of algre of a simple type that served as the agency for the precipitation of vast quantities of calcareous matter."

At this point I may stop for a moment to consider the deductions to be drawn from the presence of red beds. Most geologists interpret the presence of red beds as an indication of aridity. On the contrary. it seems to me that the evidence is fairly conclusive that red beds may have been formed under conditions of warm, moist climates. Briefly, the reasons for this view are as follows: 1 . So far as known, red beds are not being formed at the present time in any desert region, but as maturely weathered residual soils they are being formed in southern temperate and tropical regions, and in warm, moist climates. 2. Tho plants found in red beds, as, for example, in the Permian, Triassic; etcetera, are not pinched or depauperate, nor do they exhibit marked xorophytic adaptations. Moreover, very considerable deposits of coal are found in red beds in many parts of the world, which implies the presence of swamps but little above sealevel.

On the basis of the assumption that the extensive red beds in the Algonkian indicate warm, moist climatic conditions, and that the algae call for warm waters, I venture to interpret the climate of at least

5 C. D. Walcott: Pre-Cambrian Algonkian algal fiora. Smithsonian Misc. Coll., vol. 64 , no. 2, 1914, pp. 77-156, pls. 4-23. 
upper Algonkian time as warm, perhaps subtropical. Coordinative data from the side of animal life consist of about five types of trails or burrows and fragments of a supposed crustacean (Beltina).

Cambrian and Ordovician floras.-Plant life of Cambrian and Ordovician time is practically unknown. Walcott speaks of having seen a number of algal forms in certain Cambrian formations that appear to be at least generically similar to those described by him from the Algonkian, but they are still undescribed. He adds: "The field of investigation, however, is a large one, and promises most interesting results."

An appeal to the animal life of the time shows that it was becoming increasingly abundant and diversified, and, so far as I am able to learn, it indicates warm waters, wide-practically world-wide-distribution, and absence of marked climatic differentiation. As an example, mention may be made of certain stony corals (Archæocyathidæ) of the Cambrian that are found in California, Labrador, New Liberia $\left(70^{\circ} \mathrm{N}\right.$.), Sardinia, Spain, Australia, and Antarctica.

There is every reason to suppose that plants were equally abundant and equally undergoing diversification; but, as they were still confineci to an aqueous habitat, they have left little trace of their existence, unless they had the power of secreting lime.

Silurian floras.--Our knowledge of the plant life of the Silurian is still extremely limited. It consists in the main of marine algæ, and of these some 15 or 20 supposed generic types are recognized. A few or the best defined types are thought to indicate with a reasonable degree of certainty the presence of the modern groups Caulerpacex, Floridaceæ, and Fucacex, but the majority are so poorly defined that it is unwise, if not impossible, to attempt to refer them with certainty to living groups.

Devonian floras.-The coming of Devonian time witnessed one of the most important events that has been recorded in the entire history of plant life. It was then for the first time-at least in force-that plants emerged from an aqueous habitat and began their conquest of the land. In early Devonian time the land-masses were in the main low and flat, with low coasts and deep bays bordered by broad marshes, in which the surface was intermittently covered by brackish or fresh waters that seern likely to have offered a favorable setting for this momentous transformation. White ${ }^{b}$ says :

"It seems permissible to suppose that the ancestors of the land plants were amphibious, perhaps growing where exposed only at the recession of the tide. It is, I believe, probable that these early plants were but sparsely foliate,

\footnotetext{
- David White: Upper Paleozoic floras, their successlon and range. Outlines of geologic history, 1910, p. 140.
} 
their leaves being either spinoid or very small, and delicately thin. The latter were probably dorsally rolled at first during the intervals of exposure to the air. - . The expansion of a proper leaf and the production of an aerial system of transpiration were presumably gradually evolved as the plant became weaned from its subaqueous habitat, and accustomed to gain its food from the atmbsphere. However this may be, it is fairly clear that the early representatives of the dominant Devonian types were of limited foliar expanse. . . . It also appears that to support their. weight in air a reinforced cuticle, later developed as a very thick and complicated cortex, was made to serve until a woody axis, and, eventually, secondary wood should be fully produced by their descendants. From the characters of some of the fossils it seems probable that, unable to stand alone, they sprawled or clambered about on the ground or on other plants."

The known land flora of the early Devonian is very scanty indeed. The vegetation of the time had but recently emerged from an aqueous habitat, and, it is to be presumed, was of thin-leaved, hence weak, flaccid type, differing but little from the water-inhabiting ancestors. The matrix in which it should be found is coarse-grained, and, moreover, the vicissitudes to which the rocks were subsequently subjected have made it almost impossible to recover recognizable plant remains, even if such were present.

But evolutionary development was rapid and by Middle Devonian time a considerable number had assumed an upright position, though of very strange and forbidding aspect. Perhaps the most characteristic types are Psilophyton, Arthrostigma, Rachiopteris, and the peculiar fernlike plant known as Archoopteris. According to best information avail. able Archoopteris is not a true fern, but is a pteridosperm, showing that it had already developed the seed-bearing habit which would seemingly imply a very considerable developmental history. The huge fern trunks of Caulopteris show that the erect habit had gained marked headway.

As regards the place of origin of the Middle Devonian flora, White says: "Though eastern America has contributed most to our knowledge of this flora, it is probable that either the estuaries of northwestern Europe or the Arctic regions offered the conditions most favorable to its development. It extends both east and west in a high degree of unity." It has not, however, been found in the Southern Hemisphere.

On coming to the Upper Devonian we find the land flora well established and in full swing. It shows little evidence of climatic change from the Middle Devonian, but exhibits a number of new types such as Pseudobornia, a probable protocalimarian ancestor, several ferns, a probable ancestor of the Lycopodiales, and a Lepidodendron-like form as well as Archoopteris and trunks of Cordaites (Dadoxylon). In at 
least two groups, one of which (the Cordaitales) probably formed forests, the seed-bearing habit was clearly established, though both failed to survive the Paleozoic.

The place of origin of this flora was apparently in eastern Nortin America or the adjacent Arctic regions. It was, however, much more widely distributed, many of the same, or closely related forms, ranging from Pennsylvania and New York through eastern Canada, Ellesmereland, Spitzbergen, Bear Island, in the Arctic Ocean, the Don region of Russia, the British Islands, Belgium, and even reaching Queensland and Victoria. There is a noteworthy bed of coal of this age, $3 \frac{1}{2}$ feet in thickness, on Bear Island.

The interpretation of the climatic conditions under which the Devonian floras existed is beset with difficulties. So little is definitely known concerning the flora of the early Devonian that not much can be said of the probable climatic requirements, though it is difficult to understand how this flora, so newly emerged from the water and composed of thin, delicate-leaved types, could have endured except under uniform and moist conditions, and it seems a safe inference that the temperature must at least have been warm.

The climatic requirements of the Middle Devonian flora are somewhat difficult to interpret. Strange and harsh in aspect as this flora is, it has left little in linear descent and hence it is almost impossible to know the precise conditions under which it could have lived. The fact that it is so widely distributed over the Northern Hemisphere implies that the conditions were uniform and without obvious climatic zones. Its origin in or free migration over Arctic lands points at least to mild conditions. This view is supported by evidence of marine invertebrates. Schuchert says: "Warmer conditions again prevailed in the Northern Hemisphere early in Middle Devonic times, for coral reefs, limestones, and a highly varied marine life with pteropod accumulations were of wide distribution."

The Upper Devonian floras, however, are more easily and safely interpreted. Their wide distribution, which includes not only the Eastern and Western, but also the Northern and Sonthern Hemispheres, shows that the conditions of uniformity were still maintained, while the cornplete absence of growth rings in the woods shows the absence of severe changes in temperature or intervals of prolonged drought. Thereforc the climate must have been equable and at least mild.

There is undoubted evidence of local and more or less circumscribed glaciation in the later stages of Devonian time, as, for example, in New 
York, where it has been studied by Dr. John M. Clarke. There is no indication, however, that this affected the temperature of the oceans as reflected by marine life. Concerning this point Dr. Clarke writes me as follows: "Data from the invertebrate marine faunas are not merely negative. I think they are constructively positive in favor of absence of climatic zones; that is to say, in the main corroborative of your gen. eral proposition of a uniform undifferentiated climate."

Recently Mr. G. F. Matthew ${ }^{7}$ has published a paper under the titlc, "Were there climatic zones in Devonian time?" in which he attempts to show that there are marked ecological differences between certain floras of the eastern United States and Canada, on which he predicates the climatic differences. But this is based on material that comes from beds of undoubted Carboniferous age which are compared with plants of undoubted Devonian age- the perpetuation of an error to which the author has long been wedded. No further discussion of this contention seems necessary.

Carboniferous floras.-In general.-During Carboniferous time plant life had become so abundant, so diversified, and so widely dispersed over the globe that a complete analysis of this flora in all its phases would demand far more space than is at command, hence only an outline of the salient facts bearing on the question of climatic conditions can be attempted. Although there have been some differences of interpretation there seems now to be substantial agreement on the essential points under discussion, namely, that there was an abundant supply of moisture, : wide distribution with little indication of climatic zones or marked botanical provinces, and that the climate was equable. This leaves open for consideration the fixation, if reasonably possible, of the probable temperature range.

Mississippian floras.-It might be presumed that in passing from the Devonian into the Mississippian there would be a gradual merging of plant forms, but in certain regions, at least, there is found to be a quite unexpectedly sharp difference in the floras. The early Mississippian was a time of sea expansion, and in many widely scattered parts of the world conditions became favorable for the formation of coal. This new flora, whïh, according to White,

"lived in the restricted basins of the early Mississippian consists of Triphyllopteris, the broad, large-pinnuled Aneimites, the linear type of Sphenopteria, Cyclostigma, Eokdalia, and the acuminate Lepidodendra chiefly of the corrugatim group. . . .

T G. F. Matthew : Trans. Roy. Soc. Canada, 3d ser., vol. 5, sec. 4, 1911, pp. $125-133$. 
"Either on account of land or marine barriers, or because the climatic conditions throughout the Northern Hemisphere may at the outset have been less uniform than in the preceding epoch, the different areas exhibit more or less distinct local floral differences. Thus in the Pocono of West Virginia and eastern Pennsylvanla, where Triphyllopteris and the corrugatum type of Lepldodendron are almost without competition, the former achieved a remarkable differentiation far surpassing that known in any other area. In Nova Scotia, on the other hand, the Horton series, which I regard as practically contemporaneous with the Pocono, contains the same Lepidodendra, accompanied, however, by Aneimites instead of Triphyllopteris. In both the regions the formations are in close relations with the Upper Devonian. . . . All the genera mingle in Arctic Europe and Siberia, where Cyclostigma, probably of Aretic birth, has a good development."

In middle Mississippian time the earlier flora has been largely replaced by one that is very different in aspect. Here, says White, "We find a flora essentially consisting of Rhacopteris, Cardiopteris, Asterocalamites (= Bornia), with Lepidodendron volkmannianum, and $L$. veltheimianum, accompanied by a gradually increasing group of Sphenopterids."

This flora has a very wide range in the old World. Originating or best known in western Europe, it extended westward into Siberia, and southeast probably through the Balkans and Persia to South Africa and Australia, and thence presumably by way of "Gondwana land" to Argentina, in the New World. The flora of this time in the Appalachian region is so little known that close comparisons are not yet possible.

The climate during middle Mississippian time was undoubtedly moderate and uniform. For although the members of this flora "do not attain the gigantic proportions nor the specific differentiation of their Carboniferous successors, yet the relative homogeneity and the great radial distribution of this flora argue for the absence of distinct climatic zones in the recent sense, while the apparent lack of annual rings, so far as the woods have been specially examined, is opposed to the idea of seasonal changes."

Knowledge of the upper Mississippian flora is still far from satisfactory, either as to composition or geographic range; hence only tent:ative conclusions can be drawn as to the probable climatic conditions under which it lived. From the fact that certain of the plant types exhibit somewhat depauperate, semi-coriaceous foliage, and the possible presence of growth rings in certain of the woods, White considers it as at least "provisionally admissible" that there were somewhat severer climatic conditions with more or less seasonal change.

Pennsylvania floras.-With the inauguration of Pennsylvania time 
there came a remarkable change in the flora, which was perhaps due toor in any event was accompanied by-renewed sea expansion. -Many new types were either introduced or became dominant elements, such as Cheilanthes (Pseudopecopteris in part), Eremopteris, Lonchopteris, Megalopteris, Neuropteris, Bothrodendron, Ulodendron, Lepidophlois, etcetera.

The Pottsville and Allegheny time of North America is the approximate equivalent of the Westphalian or Muscovian of the Old World and witnessed the maximum development of such genera as Alethopteris, Neuropteris, Sphenopteris, etcetera. The climatic conditions must have been very uniform, for, while there are slight differences, this flora is found to have an almost world-wide range, in fact, as White says:

"The proportion of identical species is so large as to necessitate an extraordinary lack of barriers to the freest migration. The flora of the basin of Heraclea in Asia Minor lends itself readily to correlation, stage by stage, with three corresponding formations of the Pottsville in the Appalachian trough; also, of the 33 species reported by Zeillar in a collection from the Westphalian of the Djebel-Bechar region of Russia, 25 are present in the Pottsville of the Appalachian trough."

With the possible exception of the Jurassic it seems safe to say that at no time in the history of the world has there been such uniform conditions and consequent wide distribution of plant life as that of the Westphalian. Thus we find these practically identical assemblages of plants wide-spread over western Europe; central and eastern Asia, South Africa, eastern North America, and probably southern South America, or from latitude $58^{\circ} \mathrm{N}$. to $25^{\circ} \mathrm{S}$. and from longitude $110^{\circ} \mathrm{E}$. to $100+^{\circ} \mathrm{W}$.

At the close of Allegheny time and the incoming of Conemaugh or lower Stephanian time there was quite a marked change in the flora that may or may not have been due to climatic change. The gigantic Lepidodendra had almost disappeared and their places taken by a group of: huge tree-ferns, known from the trunks as Psaronius and from the foliage as Pecopteris. This by some is interpreted as evidence of short dry seasons, which seems to be corroborative of the usual explanation of the origin of red beds, that is, as a result of distinct aridity. That there may have been some climatic modification is possible, but the mere presence of red beds can not be accepted as proof positive of aridity. On this point White ${ }^{8}$ writes as follows:

"From the paleobotanical standpoint the widely current belief that aridity in the actual sense is to be assumed as causally and almost indispensably

\footnotetext{
${ }^{8}$ David White: The origin of coal. Bureau of Mines, Bull. 38, 1913, pp. 77, 78.
} 
associated with red-bed deposition is not well founded. . . . However, in opposition to such a conclusion it must be noted that $(a)$ the flora in the red beds has not been observed to differ very markedly from that in the regions of dark contemporaneous sediments, including coal; $(b)$ the plants, though less varied, are not reduced in size, nor, possibly, in number ; $(c)$ coal, usually thin, to be sure, occurs in the midst of the red beds of the Conemaugh both in the eastern and the Rocky Mountain regions of America as well as in Europe, some of the coal being thick; $(d)$ the evidence of seasonal growth ('annual rings') in the Conemaugh woods yet examined is slight, though the rings are a little more distinct than in the Allegheny woods; $(e)$ the great calamitean growth appears unimpeded, though many of the giant species are provided with thick xylem and cortex; $(f)$ the nearest living relatives of the Psaronii-the Marattiacex-are now exclusively tropical."

From these facts it is evident that the climate of this time was mild, practically free from frost, and still abundantly supplied with moisture as attested by the formation of peat.

In the upper Stephanian, which corresponds approximately to the Monongahela of the North America section, there was a revival of widespread uniformity of climatic conditions as indicated by the thick deposits of coal in many parts of the world. There is evidence in the plants that there was an absence or nearly complete absence alike of winter cold and at least prolonged seasons of drought. White concludes:

"On the whole the paleobotanical inferences are that during Monongahela: time the climate was mild, probably subtropical, and nearly uniform over the greater part of the earth, as shown by the geographic distribution of the types that were able to extend in relative purity of association to identical species round the world from east to west, and from the latitude of England and Manchuria on the north to southeastern Africa on the south."

The testimony of the animal life of Carboniferous time as to climati: conditions is in substantial accord with that of the plants. Thus, Schuchert ${ }^{9}$ says :

"The world-wide warm-water condition of the late Devonic seas of the Northern Hemisphere was continued into those of the Lower Carbonic. These latter seås were also replete with a varied marine life, among which the corals, crinids, blastids, echinids, bryozoans, brachiopods, and primitive sharks played the important rôles. Limestones were abundant and with the corals extended from the United States into Arctic Alaska. Reefs of Syringopora are reported in northern Finland at $67^{\circ} 55^{\prime} \mathrm{N}$. . . . The marine faunas of Upper Carbonic time were fairly uniform in development, and many species had a wide distribution. . . . The very large insects of the Coal Measures tell the same climatic story. They were 'brutal robbers' and scavengers living in a tropical and subtropical climate, or at the very least in a mild climate

\footnotetext{
${ }^{2}$ Charles Schuchert: Smithsonlan Inst., Ann. Rept., 1914, p. 294.
} 


\section{F. H. KNOWLTON-EVOLUTION OF GEOLOGIC CLIMATES}

devoid of frosts. We therefore conclude that after Middle Devonian time the climate of the world was as a rule uniformly warm and more or less humid and remained so to the close of Upper Carbonic time."

Permian flora and its climatic significance.-The Permian flora presents many points of extreme interest. As already stated, during and at the close of Stephanian or Pennsylvanian Carboniferous time, the climate was uniform and mild-perhaps subtropical-and as a consequence the plants in practically identical assemblages were almost worldwide in distribution. Distinct botanical provinces are not known.

The incoming of the Permian inaugurated a series of events that produced a very profound modification of both climate and plant lifethat is, the so-ealled "Permo-Carboniferous" glaciation. This glaciation, which occurred very early in the Permian and was probably of comparatively short duration, was principally about the Indian Ocean, and affected wide areas in India, South Africa, Australia, and eastern South America. This created two sharply marked botanical provinces-a northern and a southern province. In the northern province, which includes North America, Europe, and northern Asia, the Stephanian flora was able to continue with comparatively slight change, while in the south the original flora was mainly wiped out, and later succeeded by the so-called Gangamopteris or Glossopteris flora. The dominant types are Gangamopteris, Glossopteris Tertebraria, Neuropteridium, Noeggerathiopsis; Phyllotheca, Schizoneura, Ottokaria, etcetera. This is not strictly a glacial flora, though in some places, as in Australia, it is found in a higher inter-glacial epoch. It is persumed to have originated on a land mass (Gondwana Land) about the South Pole, and being a terrestrial flora there must have been practical land connection essential to its passage from these now widely separated areas-India, South Africa, Australia, and Brazil. The existence of this former land bridge is greatly strengthened by the finding of Glossopteris by the Scott Antarctic? Expedition within 5 degrees of the South Pole.

During the time of actual glacial occupancy the climate was undoubtedly severe, and this influence extended over a wider area than was dominated by the Pleistocene glaciation. Thus, in certain woods found rather closely associated with these early boulder beds in Australia and South Africa, the growth rings are indicative of sharp seasonal changes, but it is evident that very soon after the close of glacial activity greatly ameliorated climatic conditions were soon restored, for woods in the higher beds, as in South America, show very little evidence of seasonal growth rings. This early restoration of favorable climatic conditions 
is further shown by the fact that certain types characteristic of the northern province, such as Lepodendron, Lepidophlois, Sphenophyllum, etcetera, had penetrated the southern province, and Gangamopteris and $G$ lossopteris had been able to reach the northern province in northern Russia.

White, ${ }^{10}$ writing of these conditions, says:

"The conditions which brought the new flora into being banished or exterminated the cosmopolitan or northern Permo-Carboniferous flora from the Gangamopteris province. The early return of a few of the hardier lycopodiaceous forms in Argentina, Brazil, and South Africa has already been mentioned. Most of the former plant population of the province died in exile, and only their posterity, especially among the Cladophleboid forms and the Araucarian, Ginkgodean, and Cycadalean gymnosperms were able to traverse the lost territory and contest the Gangamopteris occupation."

Triassic floras.-Rocks of 'T'riassic age are known in many parts o! the world and indicate two types of deposition, a fresh-water, marsh, or lagoon phase and a marine phase, the latter being by far the most extensive, which accounts for the meagerness of the flora. Owing to various considerations, physical and otherwise, concerning which there is not complete agreement, the lower portions of the Triassic afford but scanty plant remains, and it is not until we come to the upper portion, ur Rhrtic, that it can really be dignified as a flora. Our American Triassic is thought to belong largely to this portion.

The known plants of the Triassic are relatively few in number. In North America there are less than 150 species known, and the whole Triassic flora that has been recovered hardly exceeds 400 forms. The principal North American areas are in North Carolina, Virginia, and Pennsylvania, with relatively few in Maryland, New Jersey, Connecticui, and Massachusetts. In the West we have a doubtful plant or two from Wyoming, a considerable number from New Mexico, and the extensive fossil forests of Arizona. To the southward we have small collections from Sonora, from about the City of Mexico, and in the State of Oaxaca also in Honduras, Chile, and western Argentina. In other parts of the world Triassic plants have been found in England, the east coast of Greenland and various islands in the Arctic Ocean, Spitzbergen, north Germany, southern Sweden, Italy, southwestern Spain, Persia, India, China, Tonkin, Japan, New South Wales, New Zealand, and Sout? Africa. Many identical or closely related species are widely distributed. The dominant plant types of the Paleozoic have largely disappeared.

${ }^{10}$ David White: Jour. Geology, rol, 15, 1907, p. 628. 


\section{F. H. KNOWLTON-EVOLUTION OF GEOLOGIC CLIMATES}

The Lepidodendræ, Sigillariæ, Calamites, Cordaites, Sphænophyllæ, an:L Cycadofilices, so far as ascertained, have all disappeared, as well as a number of important genera of ferns-Cheilanthes, Mariopteris, Megalopteris, etcetera. The most notable survival of the Paleozoic flora is the so-called Glossopteris flora, which has been found with a few associated forms in Rhætic rocks at Tonkin, the Stromberg series of South Africa, in New South Wales, etcetera.

The Triassic flora consists essentially of ferns, equisetums, cycads, and conifers of many genera. A few forms, such as Ginkgo, Cladophlepis, Thinnfeldia, etcetera, had a small beginning in the Paleozoic and expanded in the Mesozoic into large groups.

It has often been said that the plants of the Triassic are depauperate and pinched in aspect, which is interpreted as indicating unfavorable environmental or climatic conditions, but the paleobotanical facts do not altogether bear out this contention. The earlier Triassic rocks are largely composed of so-called red beds that are interpreted by many geologists as an indication that they were laid down under condition: of aridity. As already pointed out, this view has been brought more or less in question of late, but whatever the result of the discussion the fact remains that they are largely barren of fossils, and hence our knowledge of the flora-especially the upland flora-of early Triassic time is limited. In the Upper Triassic rocks, however, there is every indication that climatic conditions were not unfavorable to vigorous plant growth. Thus in North Carolina, Virginia, and Arizona there are trunks of trees preserved, some of which are 8 feet in diameter and at least 120 feet long, while hundreds are from 2 to 4 feet in diameter. Many of the ferns are of very large size, indicating luxuriant growth, while Equisteum stems 4 to 5 inches in diameter are only approached by a single living South American species. The cycads and conifers are not more depauperate than those of subsequent horizons, nor do they compare unfavorably with the living representatives. The complete, or nearly complete, absence of growth rings in the tree-trunks indicate that there were no- or but slight-seasonal changes due to alternations of hot and cold or wet and dry periods. The accumulation of coal一in the Virginia area aggregating 30 to 40 feet in thickness-indicates long. continued swamp or marsh conditions, while the presence of tree-ferns seems to indicate, on the whole, a moist, warm, probably at least subtropical, climate.

Late Triassic and early Jurassic time.--During late Triassic time there was renewed crustal movement, as evidenced by volcanic activity 
on a great scale in many parts of the world, but notably along the Pacific from central California to Alaska, and along the eastern Atlantic from Virginia to Nova Scotia. Schuchert says:

"Just how important this movement was and what effect it had upon the climate is not yet clear, but there is important organic evidence leading to the belief that the temperature was considerably reduced during latest Triassic and earliest Jurassic time."

He then points out that of the 1,000 or more species of Triassic ammonites not one is known to have survived into the Jurassic. The insects of the Liassic, of which group over 400 species are known, appear to hare been quite uniformly dwarfed in size, which is interpreted by Handlirsch as indicating a cooling of the climate, perhaps to that of the present temperature of northern Europe between latitudes $46^{\circ}$ and $55^{\circ}$.

From these data Schuchert concludes thus: "We therefore are seemingly warranted in concluding that the cooling of the climate in late Triassic and early Jurassic time was not local in character, but was rather of a general nature."

According to Schuchert the evidence offered by the marine invertebrates is in substantial agreement with that of the plants. The latis Paleozoic forms were almost wholly replaced by a new assemblage, and certain forms, especially in Middle and late Triassic time, attained aut extremely wide distribution. Schuchert says :

"We may therefore conclude that the rigid climate of the Permic had vanished even before the earliest of Triassic times, and that the climate of the latter period until near its close was again mild and uniform, though semiarid or even arid the world over."

James Perrin Smith, after discussing the very wide range of certain iimestones with thick coral reefs, interprets the evidence as indicating a "nearly uniform distribution of warm water over a great part of the globe" during Triassic time.

Jurassic floras.-In the lower portion of the Jurassic we find indications of a continuation of conditions which obtained in the upper portion of the Triassic. The distinctive Paleozoic elements had finally disappeared, and the Mesozoic life forms were in full swing, expanding in the middle and upper parts of the Jurassic into the abundant and wide-spread flora as we now know it. In fact, the Jurassic flora enjoyed in many respects the most marvelous distribution of any known flora, either living or fossil. It is known to range from Franz Josef Land, $82^{\circ} \mathrm{N}$, to Hope Bay, Graham Land, $63^{\circ} \mathrm{S}$., and from extreme western 


\section{F. H. KNOWLTON-EVOLUTION OF GEOLOGIC CLIMATES}

Alaska entirely around the earth to eastern Australia, or through more than $155^{\circ}$ of latitude and more than $230^{\circ}$ of longitude. Throughout this vast, practically world-wide area, there is a remarkable uniformity of distribution that is not only in individual species widely spread, but considerable assemblages of species. Thus of the 17 species known fron Cape Lisburne, Alaska, 8 are found in Amurland, eastern Siberia, 7 at Irkutsk, 6 near Kamonka, Government of Kharkow, and 4 each in Mongolia and Caucasia and Turkestan, while with the Island of Bornholm, Sweden, there are 4 species. in common, and 4 species occur in the, English beds, and 8 in Douglas County, Oregon. Of the 101 forms found in the Jurassic of Oregon and California, 47 have an outside range, there being 19 species common to eastern Siberia, 16 species at Yorkshire, England, 5 species at Hope Bay, Graham Land, and smaller numbers at widely scattered localities. Of the 23 species from Hope Bay that are known elsewhere, 4 species occur in India, 9 at Yorkshire, England, and, as already stated, 5 on our own Pacific coast.

This distribution shows conclusively that there was not only free communication between the Eastern and Western Hemispheres, but also between the Northern and Southern Hemispheres, and as none of this Jurassic plants is known to possess any peculiar mechanism for dispersal, it is apparently clear that there must have been a continuous or practically continuous land connection throughout this vast area. It is also evident that this wide distribution could only have been possib!e. under very uniform climatic conditions. It remains to consider what those climatic conditions probably were.

The Jurassic flora that has been recovered to us numbers approximately 500 species, distributed among the following groups: Algales, Marchantiales ?, Filicales, Lycopodiales, Equisatales, Cycadales, Bennettitales, Ginkgoales, and Coniferales.

The algæ and liverworts are so few in number and in general so obscure and poorly preserved that little of value can be concluded regarding the environmental conditions under which they lived. The ferns are numerous in genera and species and usually abundant as individuals. A number of the fern genera have not yet been placed systematically, for the reason that their essential organs have not been found, but, on the other hand, there are a considerable proportion in which these features are known, and hence these can be interrogated with a great degree of certainty as to the presumed climatic requirements. Thus we have Osmundites, Todites, and Cladophlebis, that belong to the Osmundacex, the living members of which are largely tropical. Kluckia and Ruffordia 
are referred to the Schizæacex, now almost wholly tropical. Gleichenites of the Gleicheniaceæ is mainly tropical. Laccopteris and Matonidium of the Matoniaceæ have the living representatives wholly tropical. Coniopteris and Dicksonia of the Cyatheaceæ are mainly tropical aud subtropical. Dictyophyllum and Hausmannia of the family Dipteraceit have the living forms wholly tropical.

Besides these there are other genera not so definitely placed, such as Polypodium, Scleropteris, Adiantites, Tæniopteris, Sagenopteris, Danæopsis, etcetera. These have been characterized on the basis of resemblance to the living forms (Polypodium, Adiantum, Tænia, Danæa, etcetera), and on this basis there is no reason to suppose they lived under conditions greatly unlike the habitat of the living analogues.

The Jurassic cycads are abundant in types as well as individuals, whence, of course, the designation of the Jurassic as the age of cycads. Approximately 25 genera of cycads are known from the Jurassic, including trunks so preserved as to exhibit all details of internal structure and reproduction, separate flowers (Williamsonia), and leaves, cones, and seeds of many types. The living cycads number 10 genera and about 80 species, and are essentially tropical in their present distribution, though a few forms are able to endure moderate cold or even frost.

The Ginkgoales is represented by a single genus (Ginkgo) and a single living species now confined to Japan, though there is some doubt as to its occurring in a wild state. It has, however, been grown for ornament in many mainly warm temperate parts of the world, although it can withstand several degrees of frost. Ginkgo is very abundant in the northern Jurassic and shows great diversity of leaf-forms, many of which have been given specific standing, though it is perhaps doubtful whether they should not be considered as representing a single polymorphous species.

The Coniferx, although numbering twenty or more nominal genera, were not an especially dominant element in this flora, and a number of them are so fragmentary and badly preserved that their affinities can not be made out with satisfaction. All things considered, however, they appear to belong mainly to types that now find a congenial habitat in warm, not to say subtropical, lands.

Based on the above facts the following conclusion is reached regarding the probable climatic conditions during Jurassic time: The presence of luxuriant ferns, many of them tree-ferns, equisetums of large size, cycads, and conifers, the descendants of which are now found in southern lands, all point to a moist, warm, probably subtropical climate.

XXXVI-BUt.L. Geoc. Soc. AM., Vot. 30, 1918 
In 1883 Neumayr, ${ }^{11}$ basing his deductions on a prolonged and intensive study of the ammonites, announced the conclusion that during Jurassic and Cretaceous time there were distinct climatic zones not unlike those now obtaining, that is, that there were clearly marked equatorial, temperate, and cool polar climates. Although this view obtained quite wide acceptance for a time, it is now very generally discredited, and it is held that his supposed temperature belts are only faunal realms. For instance, Dr. T. W. Stanton permits me to say that in his extensive studies on the distribution of Jurassic faunas from Texas to Alaska he has failed to find any indication of climatic zones, and Burckhardt ${ }^{12}$ has had a similar experience in his studies of the Jurassic faunas of northern South America and Mexico, where he found a striking mixture of types that should appertain to two or more distinct climatic zones as interpreted by Neumayr.

Recently Gothan has described some supposed Jurassic woods from King Karl's Land $\left(79^{\circ}\right.$ N.) which show very distinct growth rings, thus offering support, it is contended, of the existence of climatic zones such as advocated by Neumayr. It now appears, as pointed out by Burckhardt, that there is much doubt as to these woods having beer correctly referred to the Jurassic. From the account of the geology of. King Karl's Land as worked out by Nathorst, it is apparently established that the woods come from beds that are certainly younger than Neocomian and may indeed be Tertiary in age.

In discussing the faunal evidence as to Jurassic climate Schuchert ${ }^{1:}$ still adheres to the contention that there were three "clearly marked temperate zones," and then speaks as follows:

"That the oceanic waters of Middle and (somewhat less so) Upper Jurassic times were warm throughout the greater part of the world is seen not only in the very great abundance of marine life-probably not less than 15,000 species are known in the Jurassic-but also in the far northern distribution of many ammonites, reef corals, and marine saurians. The Jurassic often abounds in reefs made by sponges, corals, and bryozoans. Jurassic corals occur 3,000 miles north of their present habitat. . - . The insects of this time were again large and abundant, indicating a warm climate - evidence in harmony with the plants."

Cretaceous floras.-Lower Cretaceous.-So far as regards the onmarching procession of plant life it is impossible to draw any very sharp

11 M. Neumayr: Ueber Klmatische Zonen während der Jura und Kreidzeil. Denk. math. naturw., Classe d K. K. Akad. Wissensch., Wien, vol. 47, 1883.

12 Carl Burckhardt: Sur le climat de l'epoque Jurassique. Mexico, 1907.

1s Charles Schuchert: Smithsonian Inst., Ann. Rept., 1914, p. 300. 
line between the Jurassic and the overlying Cretaceous; in fact, geologists are not altogether agreed as to just where the separation is to be made. By common consent, however, it is now pretty generally accepted that the line of the Lower Cretaceous shall be drawn at the base of the Wealden, that is, the Neocomian of the European time scale. Planibearing beds in this approximate position are abundant and very wide. spread, occurring in England (44 genera, 75 species), Belgium (20 genera, 30 species), France ( 7 genera, 12 species), Switzerland ( 9 genera, 12 species), Portugal ( 45 genera, 89 species), Germany ( 33 genera, 50 species), Saxony ( 20 genera, 30 species), South Africa (16 genera, 21 species), New Zealand (2 genera, 2 species), Japan (19 genera, 28 species), China ( 4 genera, 6 species), Spitzbergen (18 genera, 32. species), and Peru ( 6 genera, 8 species). Coming to North America we have the Patuxent formation ( 70 genera, 140 species) of the Potomac group, the Kootenai formation (41 genera, 82 species) of the northern Rocky Mountain region, the upper Knoxville (23 genera, 35 species) beds of California, and beds of approximate age on Queen Charlotte Islands (10 genera, 14 species).

Berry ${ }^{14}$ has written as follows concerning these early Cretaceous floras:

"It is apparent that the dominant types of the late Jurassic floras continued without marked change throughout the older Cretaceous. These are the ferns, cycadophytes, and gymnosperms. We know little about the Thallophyta, the Bryophyta, or the Lycopodiales. The Equisetales had evidently dwindled to proportions strictly comparable to their present-day deployment. The more characteristic fern families of the older Mesozoic, such as the Marattiaceæ, are greatly reduced in importance, and the families Schizæaceæ, Gleicheniaceæ, Matoniaceæ, Osmundaceæ, and Dipteriaceæ, which are of great importance in the early part of the Lower Cretaceous, were destined to be overshadowed by the Polypodiacer before the close of the Cretaceous. Pteridospermæ are unknown, and it is within reason to suppose that this class was no longer represented in the flora of the world.

"The Cycadophytes of the early Cretaceous are essentially the familiar types of the late Jurassic. They are abundant in genera, species, and individuals, and are quite as dominant an element in the earlier Cretaceous as in the Rhatic and Jurassic floras. Before the close of the Cretaceous, however, they became extinct. The other gymnospermic types - the Ginkgoaceæ, Taxacex, and Pinaceæ-are all represented in the early Cretaceous floras."

It has been thought by some that the Angiospermæ, the now dominant modern type of vegetation, was introduced in the lowest Cretaceous (Patuxent) of eastern North America. Fontaine described three forms

\footnotetext{
14 E. W. Berry : Malyland Geol. Survey, Lower Cretaceous, 1911, p. 147.
} 
(Rogersia, Ficophyllum, Proteæphyllum) which he regarded as belonging to this class, but Berry has expressed doubt as to the correctness of. this contention, and although they certainly simulate angiospermous plants, it is perhaps best under the circumstances to await further data before definitely accepting or rejecting them.

As to the probable climatic conditions under which the earliest Cretaceous plants existed, Berry says that the "floras are so different in every way from those of the present that it is unsafe to lean too strongly on the facts which may be deduced from the present climatic distribution of the sometimes remotely related representatives of these ancient types in the existing flora."

It is undoubtedly true that we must approach this matter with a measure of caution, yet a number of undeniable facts seem established. The presence of these floras in Peru, $15^{\circ}$ south of the Equator, and in Greenland and Spitzbergen, $78^{\circ}$ north, as well as their wide range over both hemispheres, points to relatively uniform and equable conditions. whatever the temperature may have been. The petrified woods show relatively slight seasonal changes, that is, the active growth-ring is very wide and composed of large cellular elements, while the area of restricted growth is very narrow and irregular, and "is as readily explained by a dry season as by a cold winter." Another important fact is that there are no certainly known deciduous forms. The size and vigorous growth. of most of the vegetation indicates. an abundant supply of moisture, well distributed throughout most of the annual cycle. Further, if we compare the several types of plants with their obviously nearest living relatives, it seems a fairly reasonable assumption that their temperature requirements could not have been greatly different. Therefore, I feel justified in holding that the climate of early Cretaceous time was equable, moist, and fairly warm, that is, at least very warm temperate.

The Barremian of the European scale is believed to be represented in eastern North America by the Arundel formation, which contains a small flora mainly of ferns, cycads, and conifers, but with several of the doubtful angiospermous types mentioned as occurring in the Patuxent formation. Of similar age is the so-called Kome flora of Greenland, which includes 88 species, over 40 of which are ferns, while there are 18 conifers, 11 cycads, and 3 each in Ginkgo and Equisteum. There are also two undoubted dicotyledons, though there is grave doubt as to their having come from these beds. In the Eastern Hemisphere there has been noted a large flora ( 23 genera, 45 species) from Portugal, and small floras from England ( 7 genera, 17 species), France (8 genera, 9 
species), Austria-Hungary (22 genera, 29 species), and Eurasia (18 genera, 23 species). These floras are made up mainly of ferns, cycads, and conifers, no dicotyledons being known to be present.

The Aptian is believed to be represented in North America by the Glen Rose limestone of Texas, with 16 genera and 25 nominal species, of which 8 are cycads, 11 conifers, and 1 fern, and by the Lakota sandstone of the Black Hills region, which includes 21 genera and 59 species, there being 13 ferns, 33 cycads, and 8 conifers; neither includes dicotyledons.

In Europe the Aptian is known from France ( 2 genera, 2 species), Germany (9 genera, 12 species), Italy (13 species, 1 genus of cycads), and Portugal (21 genera, 25 species), the cycads predominating and angiosperms absent.

The uppermost portion of the Lower Cretaceous, the Albian of Europe, witnessed $\rightarrow$ at least in extenso-the formal establishment of the since dominant angiospermous types of vegetation and the beginning of the decline of ferns, cycads, and conifers. The Patapsco formation of Maryland and Virginia has afforded a flora of not less than 60 species. of which number 25 are undoubted angiosperms. These are so diversified in type and so highly organized as to suggest strongly a long pre. vious period of development, but we do not yet know when or just where the evolution took place. They began immediately the conquest of the earth, and the Fuson formation of the Black Hills region, though stili having a preponderance of ferns, cycads, and conifers, included some half dozen angiosperms.

In beds of Albian age in Portugal there is a considerable fiora ( 36 genera, 66 species) which embraces 20 ferns, 6 cycads, 18 gymnosperms, and 22 angiosperms, a number of which are identical with species in the Patapsco formation. The Upper Albion of Portugal contains a flora of 15 genera and 26 species, but has no ferns or cycads and but a single conifer, the remainder being all angiosperms. Small floras of Albian age are known from England ( 3 genera, 8 species) and France ( $1 \%$ genera, 35 species), but they are without known angiosperms.

As regards the climatic conditions that may fairly be presumed to have obtained during the upper part of the Lower Cretaceous, I can see no reason for supposing that it was greatly different from that alreadr. indicated for the lowest Cretaceous, namely, equability, abundant moist. ure well distributed throughout the year, and a temperature that was at least warm temperate. 


\section{F. H. KNOWLTON-EVOLUTION OF GEOLOGIC CLIMATES}

Upper Cretaceous.-By the beginning of Upper Cretaceous time, assuming that the Albian is correctly placed in the Lower Cretaceous, though this view is not always accepted, the angiosperms had assumed dominance, and the ferns, cycads, and conifers had fallen to the subordinate position they have since held. In the earliest members of the Upper Cretaceous the angiosperms had already been differentiated into the two groups of monocotyledons and dicotyledons. These new types spread so rapidly and so widely that it will be impossible fully to consider the great number of plant-bearing beds in the many parts of the world.

In certain particulars the most important of these Upper Cretaceous floras are those of the Greenland, which occur mainly on the Nugsuak Peninsula from latitude $69^{\circ} 15^{\prime}$ to $72^{\circ} 15^{\prime} \mathrm{N}$. This, it will be noted, is well within the Arctic Circle. The oldest flora-that of the Atane beds-comprises 88 genera and 181 species, 70 per cent of which are dicotyledons. Overlying this is a thick series of beds-the Patoot bedsthe upper portion of which may show transition into the Tertiary. The Patoot flora includes 72 genera and about 122 species, 80 of which are dicotyledons.

Plant-bearing beds, similar if not indeed identical in age with the Atane beds, are found in the Raritan formation, which extends along the Atlantic Coastal Plain from Massachusetts to Maryland. The Raritan flora embraces 102 genera and 220 species, 150 of which are dicotyledons. Forty-seven of the Raritan species occur in the Atane beds.

Immediately overlying the Raritan and with much the same areal disposition is the Magothy formation, with 123 genera and 275 species, 200 of which are dicotyledons. Of approximately similar age is the Dakota flora, which includes 125 genera and over 500 species. In this connection it is of great interest to note that a small but unmistakable Dakota flora has been found by Kurtz in north-central Argentina, showing that this flora spread south a distance of 5,000 miles, crossing the Equator and a land bridge that must have connected North and South America at this time.

In the. Atlantic Coastal Plain and Gulf regions there are a number of important floras in the approximate position of the Magothy and Dakota floras, altogether aggregating several hundred species, largely dicotyledons. These fl: $:$ occur in the Black Creek, Eutaw, Tuscaloosa, and Woodbine formations. In the Rocky Mountain region the Uppor Cretaceous is more or less abundantly plant-bearing, one of the most interesting being that from the Frontier formation (of the Colorado group) of western Wyoming. Although consisting mainly of dicoty- 
ledons, it concludes some peculiar ferns that find their closest relationship with species now living in the Pacific islands. The Montana group has afforded several small floras, including that of the Mesaverde formation ( $80 \pm$ species), the Vermejo formation (108 species, 51 genera), the Fruitland and Kirtland formations (40 species, 20 genera), and the Fos Hills sandstone (14 species, 12 genera). The Laramie formation as at present accepted has a flora of 129 species belonging to 53 genera.

In the Canadian provinces there are small Upper Cretaceous floras, as that of the Mill Creek series (25 species), the Belly River (about 150 species), and the northern part of Vancouver Island (81 species).

With the exception of the Dakota flora already mentioned floras of Upper Cretaceous age are practically unknown in South America and Antarctica. Australia has a somewhat doubtful flora referred to this age (61 species), and New Zealand a still smaller one (36 species). Asia, during Upper Cretaceous time, was receiving mainly marine deposits, and hence few plants are known, the most notable being from Japan (23 species). Africa has also very few plant beds of this age.

Turning now to Europe, only briefest mention can be made of the Upper Cretaceous plant deposits. Thus, only 7 species are recorded from Scandinavia and none from England, which received only marine deposits. France fared a little better, having small floras from the Cenomanian of Anjon, the Argonne, and the Ile d'Aix (15 \pm species), the Turonian of Bagnols and Mède (48 species), the Eschmerian of Beausset near Tulon (10 species), and the Atrurian of Foveau (19) species). Portugal has Cenomanian, Turonian, and Senonian floras ag. gregating about 80 species. The Italian flora is almost negligible (11 species), while the German and Austrian-Hungarian floras are very large. Thus, from the basal Campanian, in the vicinity of Aachen (Aix-laChapelle), about 150 species are known, over 80 species (Cenomanian) from Niedershœena, 25 species or more from near Dresden, and over 70 species from Saxony. From the Perucer beds (Cenomanian) of Bohemiano less than 184 species have been described, while from Moravia there are considerable floras known.

Climate of Opper Cretaceous time.-Before discussing the probable climatic conditions that seem to be indicated for Upper Cretaceous time, a word may be said as to the presumed place of origin of the dicotyle. donous floras that had spread so widely and almost coincident with the dawn of the Upper Cratecous. Although, as Berry has well said, the time has not come for a thoroughly satisfactory discussion of the origin and migration of this great flora, it bursts upon our attention with such 


\section{F. H. KNOWLTON-EVOLUTION OF GEOLOGIC CLIMATES}

suddenness as to suggest that it must have had a long anterior period of development, perhaps on some great land-mass that was not then receiving sedimentation, or is still unexplored. Berry ${ }^{15}$ continues :

"It has been assumed, and it is certainly the most attractive hypothesis, that the origin of the dicotyledons was in high latitudes from which region they spread southward over the continents of the Northern Hemisphere in successive waves of migration. There is considerable evidence in support of this theory, but the unexplored Cretaceous sediments of the great continent of Asia and most of the lands in the Southern Hemisphere invalidates too hasty generalizations. The land-mass of Asia with free land communication during Middle Cretaceous time to the northward, southward, eastward, and westward, has not received the consideration which it merits as a center of distribution, nor have the American tropics received much attention. . . . This one conclusion seems warranted, that the origin and initial radiation of dicotyledonous floras took place somewhere in the great massed land areas of the Northern Hemisphere."

Although there are marked differences between many of the more or less widely separated floras that are believed to be in approximately similar stratigraphic position, there are, nevertheless, so many species held in common as to lead to the inevitable conclusion that climatic zones such as now exist did not obtain during Upper Cretaceous time. We find, for instance, that the Atane flora ranged from Greenland along the Atlantic Coastal Plain and Gulf region to Texas with but little change, and the Dakota flora spread with practically no change from Kansas to Argentina. In fact, as Berry says, "they cross the equato:" unchanged in both the Eastern and Western Hemispheres."

The inference to be drawn from the above facts is that during Upper Cretaceous time the temperature conditions were very uniform and equable over the greater part of the earth's surface, extending from at least $72^{\circ} \mathrm{N}$. in Greenland to at least $60^{\circ} \mathrm{S}$. in Argentina, with the probability that it was practically world-wide.

The moisture conditions may next be considered. The study of these floras reveals very little evidence of deciduous habits, which implies an uninterrupted growing season and an abundant, or at least an adequate, supply of moisture, well distributed throughout the year. An example in the existing floras is shown by the warm temperate rain-forests of many parts of the world. The existence of an abundance of moisture is also further shown by the presence of very considerable deposits of coal, especially in the Rocky Mountain region, which implies wide-spread and long-continued swamp or marsh conditions.

15 E. W. Berry : Maryland Geol. Survey, Upper Cretaceous, 1916, p. 311. 
We may now attempt an interpretation of probable temperature conditions during Upper Cretaceous time. To begin with Greenland, it of course needs no argument to prove that the climatic conditions there were very different from those obtaining during and since Pleistocene time. The following Atane genera are given with their present-day distribution and climatic requirements: Artocarpus (bread-fruit tree) now confined to the Old World and within $20^{\circ}$ of the Equator. Ficus, a vast tropical genus with a few species ranging into warm temperate regions. Cinnamomum and Laurus, small genera in the cool parts oi the tropics. Pseudocycas, one species of which at least is closely related to the tropical Cycas revoluta. Aralia has about 27 living species in the temperate and warm parts of America and Asia. Panax, a small genus of eastern North America and central and eastern Asia. Pistia, a monctypic genus very widely distributed in the tropics and subtropics of both hemispheres. Cyathea (tree-ferns) embraces 100 species widely disseminated in the tropical and subtropical countries, extending in New Zealand $40^{\circ}$ S., but not occurring above the northern tropics. Gleichenia, represented in the Atane flora by six species and a profusion of individuals, is confined as now restricted by pteridologists to the tropics and subtropics of the Old World. Widdringtonites, so named from it.s resemblance to Widdringtonia, a genus of four species now living in. South Africa and Madagascar.

There are other genera in the Atane flora whose living representatives have a more or less extensive representation in temperate regions, some of which also have representatives in warm temperate and even in subtropical regions. These are Acer, Asplenium, Cassia, Cissites, Diospyros, Hedera, Ilex, Magnolia, Myrsine, Palaurus, Pinus, Pteris, Quercue, Sapindus, Selaginella, etcetera.

From the above presentation of facts it seems safe to conclude that the climate of Greenland during Atane time could not have been cooler than warm temperate, and when we consider the presence of bread-fruit trees, figs, cinnamon trees, tree-ferns, etcetera, it might well have been at least subtropical. Heer concluded the Atane flora probably flourished in a climate with a mean annual temperature of $19-20^{\circ}$ C. Some students have placed the temperature higher than this, and others have placed it lower.

It will be impossible, indeed perhaps unnecessary, in the space avaiiable to make as complete an analysis of the other Upper Cretaceous floras, but a few notable conditions may be pointed out. There is nothing, so far as I can interpret it, in the floras of eastern Nort? 
America that militates fatally against the conclusion that they required at least a warm temperate and possibly a subtropical climate. Turning to the Rocky Mountain region we may select the Frontier formation (of Colorado age), concerning which Knowlton ${ }^{16}$ has published as follows:

"The climate during Frontier time appears to have been tropical or subtropical, as is shown in a number of ways. Thus, one of the most abundant of the ferns (Tapeinidium) was indeterminate in growth, a condition that could survive to the extent here indicated only in the absence of frosts. The most abundant elements in this flora are the ferns, . . . and all call for a tropical or subtropical habitat. . . . The wax-berry (Myrica), the oak (Quercus), and the willow (Salix), might not be out of place in a tropical region, but the figs (Ficus) and the cinnamon trees (Cinnamomum) certainly required a tropical or subtropical location."

The flora of the Vermejo formation (of Montana age) includes breadfruit trees, 16 species of figs, fan palms of gigantic size as well as types indicating a more temperate condition, but when viewed as a whole the following conclusion was reached: ${ }^{17}$

"From the abundance and proportions of the plant types it may be presumed that there was an abundance of moisture, from the absence of marked growth rings that there was no sharp differentiation of seasons, and from the general facies of the whole flora that the climate was warm temperate and perhaps even subtropical."

Tertiary floras.-Origin of herbaceous types of vegetation.-Before discussing the various Tertiary floras it is important to call attention to a very profound change that came about in plant life at this timenamely, the evolution of herbaceous types of vegetation. During the whole of the Cretaceous and at least the earlier part of the Tertiary herbs are practically unknown, whereas in the present flora they vastly outnumber the woody types in all the cooler parts of the world. It seems to be generally accepted that the herbs have descended from woody plants in direct response to increasing refrigeration during Tertiary time. Dr. E. W. Sinnott ${ }^{18}$ has recently published a very important article or: "The evolution of herbs," from which I venture to quote the following:

"These facts-that woody plants are more ancient than herbs is shown by evidence from fossils, from natural relationships and from anatomy; that herbs are now dominant and woody plants few in species in regions subject to low winter temperatures, and vice versa; that regions which have been isolated from the north temperate land-mass possess few herbs in the ancient

${ }^{16}$ F. H. Knowlton: U. S. Geol. Survey Prof. Paper 108, 1917, p. 79.

17 F. H. Knowlton: U. S. Geol. Survey Prof. Paper 101, 1917, p. 235.

${ }^{18} \mathrm{E}$. W. Sinnott : Science, new ser., vol. 44, 1916, p. 295. 
portion of their floras, and that the northern continents supported at no very ancient day a much more varied woody vegetation than at present-all suggest the conclusion that a large part, at least, of our modern herbaceous vegetation originated in the north temperate zone in response to the progressive refrigeration of climate which we know to have taken place there during the Tertiary.

"The great adrantages conferred by the possession of an herbaceous habit of growth in a region subject to low winter temperatures are obvious, for such plants are able to complete their cycles and to mature seed in the warm summer months and can then survive the cold of winter in the form of resistant seeds or by hibernating underground. Only the hardier types can maintain permanent aerial stems under these conditions. The more delicate woody families have either been exterminated outright in temperate regions or have survived only by assuming an herbaceous habit and thus flourishing in that part of the year which is free from frost. As might be expected if low temperature has indeed been the determining factor in the development of herbs, most of those families which are well able to survive cold, as trees or shrubs, and which form the bulk of the woody vegetation of the north temperate zone-the willows, birches, oaks, beeches, walnuts, hickories, wax myrtles, elms, hollies, heaths, buckthorns, lindens, planes, sumacs, cornels, and viburnums-are families which are almost entirely without herbaceous members. Being hardy, they have not been forced to adopt the herbaceous habit.

"As to the details of this change in growth habit we can not of course be sure, but in those forms which it did not kill outright the increasing cold probably effected a gradual reduction in size and an attendant shortening of the time necessary to reach maturity, until very dwarf forms were produced which were able to develop from seed to seed in a year or two, and which could be killed back to the ground every winter-in short, perennial herbs. The herbaceous vegetation in arctic and alpine regions today is still composed almost entirely of such plants."

Interesting statistics are given by Sinnott to show this decrease of herbaceous types from arctic and alpine regions to the heart of the tropics. Thus, in Ellesmereland the percentage of herbs is 92, Switzerland 91, Iceland 90, Great Britain 89, Rocky Mountains 87, northern United States 78, Japan 5\%, tropical Africa 42, Ceylon 37, Java 27, Rrazil 26, Lowlands of the Amazon Valley 12 per cent.

The composition and distribution of Cretaceous and Tertiary floras undoubtedly lend support-shall I say proof-to this view regarding the origin of herbaceous types. Their absence during Cretaceous and much of Tertiary time had long ago been noted, and their absence from these floras was explained on the ground of their usually small size, delicate structure, and generally non-deciduous leaves, but this explanation of their descent from woody types explains much that was before r,bscure.

Eocene floras and their probable climatic requirements.-Although a 
very considerable number of modern plant types were undoubtedly established by the end of Cretaceous time, there are nevertheless notable differences to be observed in the composition of the floras of the Cretaceous and Tertiary. Much of the sharpness of this distinction has in the past been lost or obscured by the vicarious placing of the line between Cretaceous and Tertiary. This has been especially true in North America, where the placing of such important plant-bearing units as the Raton, Dawson, Denver, Lance, etcetera, in the Cretaceous has had unfortunate effects; but now, supported by important diastrophic data, it seems to be pretty generally conceded that they properly belong in the Tertiary. As bearing on the distinctness of Cretaceous and Tertiary floras, it may be stated that approximately 40 per cent of the genera in existence in the Cretaceous had become extinct at the close of that time.

North America is fairly rich in Eocene floras, especially in the Guli region, Rocky Mountain region, and in the northern Pacific coast region. The oldest of the plant-bearing units in the Gulf region is that of the Midway formation, but the known forms are so few that they become negligible in the present connection. Above the Midway is a thick series of sediments known as the Wilcox group, which has a flora of 134 genera and over 330 species. The Wilcox flora has been fully elaborated by Berry, ${ }^{19}$ who points out that it is "overwhelmingly that of a strand flora, of which some of the elements indicate that they grew on the sandy beaches, others in muddy tidal flats, others between or behind dunes or beach ridges, and others in estuary bayous or marshes. None of the forms can certainly be considered as inland or upland types."

Berry says further:

"It may be noted that all of the Wilcox plants, almost without exception, are plants whose modern representatives inhabit the warmer parts of the earth. There is not a single strictly temperate type in the whole assemblage. . . Compared with recent costal floras, it is at once apparent that its affinities are entirely with those of tropical and subtropical America. . . . It is obvious that the flora could not have existed if the region was ever visited by frost, and temperatures appear to have been like those found today on the Florida Keys."

In other words, a subtropical rain forest.

Of approximately the same age as the Wilcox, or possibly slightly older, is the flora of the Raton formation of the Raton Mesa region of New Mexico and Colorado. This flora contains 148 species, over 40 of which are identical or closely related to those of the Wilcox flora. One

10 E. W. Berry :- Proc. Am. Philos. Soc., vol, 53, 1914, p. 135 ; U. S. Geol. Survey Prof. Paper 91, 1916, p. 74. 
of the most conspicuous and dominant elements in this flora was the palms, of which there were at least 6 genera and 9 species, some of them being exceedingly abundant in individuals. The 15 species of fig: (Ficus), as well as 3 bread-fruit trees (Artocarpus), undoubtedly argue for a warm climate. Magnolias were also abundant and likewise predi. cate a warm climate, as do the laurels (Laurus), cinnamons (Cinnamomum), and related forms. The presence of numerous coal veins, as well as the character and luxuriance of the regetation, indicates that moisture was abundant, and the known distribution and requirements of the living representatives of the Raton flora make it more than probable that the climate was at least warm temperate.

Correlated with the last is the Denver formation of northern Colorads, with a flora of approximately 200 species. The physical conditions under which it grew were apparently the same as for the Raton flora.

The flora of the Lance formation of Wyoming and the Dakotas has not been thoroughly studied, though so far as worked out it is so closely related to that of the Fort Union that for present purposes they may be considered together. The Fort Union occupies a vast area from Wyoming and the Dakotas, Montana, and the central Canadian provinces to the valley of the Mackenzie River. It has a flora of some 500 species. Although there are palms of large size in the lower portions of the formation, the bulk of the flora is made up of sequoias, cedars, yews, grasses, sedges, oaks, willows, poplars in great abundance and variety, hazelnuts, walnuts, elms, sycamores in profusion, maples, viburnums in great variety, and a few somewhat doubtful figs. This flora, which is closely similar to that in north Greenland, undoubtedly approached from the north. Notwithstanding the presence of palms, which, however, occur in the lower parts of the beds, the composition of this flora seems to indicate that temperatures were considerably lower than for those Eocene floras already reviewed-in fact, that it was temperate, perhaps what would be, called cool temperate.

In the northern Pacific coast region there are a number of Eoeenc floras, among them that of the Swauk, which occurs just east of the Cascade Mountains in Washington. This large flora is different from any other yet made known in this country, and consists largely of types that are for the most part found in Central and South America, among them being fan-palms 6 feet in diameter and in layers sometimes a foot in thickness. This shows that the palms were not sporadic or occasional, and indicates, as do many of the other things, that the climate was mild, probably even subtropical. The overlying Roslyn formation contains a 
flora that is almost entirely different from that of the Swauk and, lacking the presence of palms, was apparently slightly cooler than the temperature obtaining during the deposition of the underlying beds.

At Cherry Creek, Oregon, there occurs a small lower Eocene flora of 20 species in beds of the lower part of the Clarno formation. It is a warm temperate flora. Almost the only known middle Eocene flora found on this continent is that of the Green River formation of western Wyoming. It has a flora of about 80 species, mainly of very modern types, among them such as Acrostichium, Lygodium, Mannicaria, Musophyllum, Sapindus, Zizyphus, etcetera, which indicate a climate considerably warmer than the Fort Union, for instance.

Another small flora of approximate middle Eocene age is the Claiborne flora of Georgia recently elaborated by Berry. ${ }^{20}$ It comprises only 17 species, but embraces such a proportion of absolutely determined forms that there is believed to be little probability of error in interpreting their requirements. It is distinctly a coast or strand assemblage, and Berry concludes that it indicates a condition approximated by the subtropical or warm temperate rain forests of the present day. Being in proximity to the warm Eocene ocean currents, it must have been uniformly humid, and the temperature "would have to be uniform rather than hot, . . . for any degree of winter cold would have been fatal."

In Alaska we have the upper Eocene Kenai formation, which has afforded a rich flora of oaks, poplars, willows, hazels, walnuts, magnolias, horse-chestnuts, and maples, together with pines, spruces, cedars, and sequoias. This flora is also found in British Columbia, and is abundantly represented in Greenland, Iceland, and Spitsbergen, showing that it was of wide extent in northern latitudes. It is distinctly a warm temperate flora.

Turning now to the Old World, we find a number of important Eocene floras, though not all have yet been worked up to the point where their data can be made full use of in interpreting climatic conditions. Thus, the basal Eocene, the so-called Paleocene of Schimper, or the Montian and Thanetian stages of subsequent writers contains two importart floras in northern France and Belgium. That of the plastic clays of Trieu de Leval (Hinaut), Belgium, as described by Marty, comprises only about 20 species and is thought to find its closest resemblance in the equatorial region of South America. The flora from the travertines of Seganne, France, elaborated by Saporta, is larger ( 87 species) and is apparently a temperate or warm temperate flora.

${ }^{20}$ E. W. Berry : U. S. Geol. Survey Prof. Paper 94, 1914, p. 129. 
The Lower Eocene contains a number of important but mainly unstudied English deposits, and at a slightly higher position the extensive deposits of Alum Bay and the London Clay in England. Our knowledge of the flora of these two localities is confined to a list of the names, but the plants have never been described or figured. The Alum Bay flora comprises 116 genera, 273 species, and that from the Isle of Sheppy 72 genera and 198 species. The plants as thus made known appear to indicate a much warmer climate than the floras of the French and Belgian deposits just mentioned; in fact, Gardner regards it as tropical. If these plants have been correctly identified-and a large proportion of them are seeds and fruits that are susceptible of close study-it is diffcult to see how the climate could have been cooler than subtropical at least.

A time of great sea extension marked the Middle Eocene in Europe, and it is only in the upper beds, such, for instance, as the calcaire grossier superieur of the Paris Basin, that plants are preserved. A small florule from the last-mentioned beds has been described by Bureau, including Pandanus, Flabellaria, Sabal, Palmacites, Yucca, and Nuphar. These indicate that the climate was still warm, probably nearly tropical.

In the southern part of England the Bogshot sands and the Bournemouth clays, as well as the beds of Antrim and Mull, contain a very large, beautifully preserved flora, but it is mostly undescribed. Gardner has worked up the ferns and conifers, among them being the generil Acrostichum, Anemia, Gleichenia, Meniphyllum, Araucaria, Cupressus, Podocarpus, and Sequoia. Certain genera of monocotyledons are indicated, such as Phœinix, Calamus, and Nipa. These seem to indicate that the climate must still have been warm and moist.

Of approximately the same age as those above mentioned are the plant beds of Monte Bolca, Italy. A warm, probably subtropical, climate is indicated by the presence of numerous and large palms.

One of the largest and best known of European and Eocene floras is that from Aix, in Provence, France, described by Saporta, which comprises over 500 species. It includes fungi, algæ (Chara), hepatics, mosses, ferns, conifers of many genera, grasses, sedges (Carex), palms (5 genera, 12 species), Smilax, irises, cat-tails; wax-berries, alders, birches, oaks, elms, figs, laurels ( 5 genera, 26 species), Daphne, Proteoides, composites, Olea, ashes, Catalpa, Myrsine, Bumelia, persimmons, Andromeda, Vaccimium, Aralia, buttercups, water-lilies, magnolias, barberry, maples, Sapindus, bittersweets, buckthorns, sumacs, Ailanthus, clover (Trifolium), and a great number of genera and species of leguminous types. 
Saporta makes elaborate comparisons of the Aix flora with that now living in various parts of the world, notably Asia and Africa, and concludes that the climate was tropical or subtropical.

Other large floras of about the same age as the last are known from Häring, in the Tyrol, and several localities in Dalmatia; but they need not be further considered here.

Miocene floras and their climatic requirements.-The known Miocene floras of North America are relatively unimportant, although in the aggregate probably somewhat over $\mathbf{5 0 0}$ species have been indicated. The deposits occur in often small isolated basins that in some cases are separated by hundreds of miles. Thus, the only flora of any importance in the entire area east of the Rocky Mountains is at Brandon, Vermont, where there are small pocket-like deposits of lignite in the midst of ancient crystalline rocks. These have yielded large numbers of fruits and seeds and a very few poorly preserved leaves. Upward of 150 nominal species have been described, many of which are referred to form genera, such as Bicarpellites, Cucumites, Tricarpellites, Brandonia, etcetera, with a few suggesting affinity to modern genera, as Nyssites, Hicoria, Juglandites, etcetera. There is so much uncertainty regarding the botanical allocation of these forms that it is impossible to draw very satisfactory or convincing conclusions as to the climatic conditions under which they grew, though obviously they must have been quite different from present conditions. However, as certain of the lignites studied show well marked growth rings, it is apparent that there must have been well defined seasonal changes of some sort.

At Florissant, Colorado, also in the midst of older crystalline rocks, there are small lake-bed deposits which have afforded vast quantities if plant and insect material that is largely in an admirable state of preservation. About 1,000 species of insects and upward of 200 species of plants have been described. According to Scudder, the insects show certain tropical affinities, but also embrace representatives of forms now living in the vicinity. Much the same can be said of the plants; for, though the general facies of the flora is abundantly different, there are a number of generic types that are now living in the region. Certain important types show relationship with the flora of the Southern States and the West Indies and indicate that the climate was considerably warmer than the present one. Large silicified trunks of Sequoia are found in these beds, and, as they show well defined growth rings, it is an indication that there were marked seasonal changes of temperature. It is also evident that there was a greater degree of moisture, and altogether it 
seems a safe assumption that the climate was at least temperate. It is important to note that a considerable number of unmistakable harbaceous types were present.

There is a small Upper Miocene flora found at Elko, Nevada, that is apparently of the same age as the Florissant lake beds, but it is too small to be of much value in the present connection. In approximately the same position is a small florule of 14 species from Esmeralda County, Nevada. It indicates a higher degree of moisture than at present obtaining and altogether a climate probably like that of the Southern States. In California the auriferous gravels have yielded a flora of some 125 species, many of them of very modern appearance, such as Acer, Artocarpus, Magnolia, Persea, Quercus, Castanopsis, Zizyphus, etcetera. On account of their obvious affinity with the living flora, they were at first referred to the Pliocene by Lesquereux, but later they came to be regarded as Middle Miocene. This flora is much in need of critical revision, and latest stratigraphic studies seem to indicate that the auriferous gravel phase may possibly have begun in the uppermost Eocene and continued on well into the Miocene. In the John Day Basin of Oregon there is the Middle Miocene Mascall flora of about 80 forms. It includes Sequoia, Glyptostrobus, Taxodium, Populus, Salix, Juglans, Hicoria, Quercus, Ulmus, Planera, Magnolia, Laurus, Platanus, Rhus, Acer, Sapindus, etcetera, and altogether indicates at least a temperate climate. In the Yellowstone National Park there are two small Miocene floras that have much the same facies as that last considered and point to much the same conclusion regarding its climatic indications. The numerous fossil trees so prominent in the park all show strongly defined growth rings. To the north, in the Canadian provinces, Dawson has signalized the Upper Miocene flora of the Similkameen Valley, a flora of some 25 forms, all indicating temperate conditions.

In the Old World many and widely scattered Miocene floras have been made known, the most extensive and most completely exploited being that of Switzerland, as described by Oswald Heer. ${ }^{21}$ This flora includes some 920 species, of which number 114 are so-called flowerless plants and 806 are flowering plants. Of the latter, 291 are species of trees and 242 are shrubs, or 533 species of woody plants. The herbaceous flowering plants number 164 species. On the basis of certain proportions between the several groups of plants, Heer concludes that the full Miocene flora of Switzerland could hardly have been less than 3,000 species, which is far in excess of the number now living there. Associated with the plants

21 Oswald Heer: Flora Tertiaria Helvetiæ, vol. 1, 1854 ; vol. 2, 1856 ; vol. $3,1859$. XXXYiI-Bull. Groc. Soc. AM., Vor. 30, 1918 
were numerous species of insects, and from their combined study Heer was able to work out many interesting conclusions, such as the succession of seasons and, above all, of the climatic requirements. Concerning the climate, Heer ${ }^{22}$ wrote as follows:

"In the Upper Miocene (of CEningen) the tropical types constitute only 7 per cent of the total number of vascular plants, whilst in the Lower Miocene (Aquitanian) the tropical types are 15 per cent of the whole, which shows that a decrease of temperature must have taken place, although the frequent occurrence of the camphor- and cinnamon-trees, and the appearance of featherand fan-palms, demonstrate that CEningen still enjoyed a warm climate.

"If we sum up all the data furnished by the flora, we are led to the conclusion that the Swiss Lower: Miocene district possessed a climate similar to that now prevailing in Louisiana, the Canaries, North Africa, and South China, namely, a climate with a mean annual temperature of $20-21^{\circ} \mathrm{C}$. (68'$69.8^{\circ}$ F.), and that the Swiss Upper Miocene district had a climate resembling that of Madeira, Malaga, and the south of Sicily, southern Japan, and New Georgia, with an annual temperature of $18-19^{\circ} \mathrm{C}$. (64-66.2 $2^{\circ}$ F.)."

Pliocene floras and their climatic requirements.-The Pliocene flora of North America is almost a negligible quantity, and is far too small to be of value in the present connection. It consists of a small florule, thought to be of this age, from the Falls of the Columbia River. It includes species in the genera Woodwardia, Sassafras, Sterculia, etcetera, all being extinct, though very closely related to living forms.

A florule of 20 species, all living today in the Coast Ranges of California, has been described by Hannibal ${ }^{23}$ from the Santa Clara formation of the Coast Ranges of California. Concerning it the author says:

"This flora agrees very well with the evidence of the aquatic Mollusca and points to perceptibly colder conditions in central California during Pliocene time, but makes it certain that this cold facies was due not to elevation, but to actual migration of isotherms. Such a condition could not have been a local phenomenon, but was probably widespread on the Pacific coast."

In western Europe, thanks especially to the persistent labor of Clement and Eleanor M. Reid, knowledge of the Pliocene flora is extensive and on an established observational basis. In England the Lower and Middle Pliocene are marine; hence are without plant deposits. The only beds yielding plants are known as the Cromerian, or Cromer Forest beds, of extreme Upper Pliocene age. Fortunately, older Pliocene beds have been discovered in Dutch Limburg and adjacent Prussia, and made known by the Reids ${ }^{24}$ in a splendid monograph published in 1915. The oldest of

20 Oswald Heer: The Primeval World of Switzerland, vol. 2, 1876, p. 138.

2 Harold Hannibal : Torr. Bot. Club Bull., vol. 38, 1911, pp. 329-342.

24 Clement and Eleanor M. Reld: The Pllocene flora of the Dutch-Prussian border. The Hague, 1915. 
these floras, known as the Reuverian stage or flora, is Middle Pliocene in age. It includes a flora, mainly of seeds and fruits, of nearly 300 species, of which some 230 have been determined with a considerable degree of certainty. This flora has very little relationship with the present flora of Europe, the Caucasus, or the Mediterranean, but clearly finds close affinity with the "Iiving flora of the mountains of western China, and to its allied geographical provinces-Japan, the Himalaya, Eastern Tibet, and the Malay Peninsula."

The Reids conclude that the Reuverian assemblage was a temperate flora similar to that which belongs to the moist and temperate forest belt found only on the Chinese mountains. The late Miocene and early Pliocene flora was originally essentially circumpolar in distribution, but increasing cold forced it southward along at least three migration routes. One path was along the mountains of Atlantic North America, a second through eastern Asia, where both persist today, and which accounts, as Asa Gray long ago pointed out, for the striking resemblance between these two floras. The third route was through western Europe, as attested. by the remains found in the Reuverian flora; but when increasing cold forced this farther south, it was crushed out against the east-west mountain ranges and disappeared.

A slightly younger flora, and one very distinct from the Reuverian flora, is the Upper Pliocene Teglian flora of Limburg. It includes about 133 forms, of a decidedly cool-temperate character, which bears a close resemblance to the European flora of the present day. That is, all the plants with Malayan and Australian affinity had disappeared, and although a few distinctive Chinese and Japanese species still remained, by Upper Pliocene time, as represented by the Cromerian from England, the European facies had been fully established, the peculiar Chinese element having disappeared, except for such species as still live in Europe.

\section{Part II. Origin and Differentiation of geologio Climates}

\section{EARLY OLIMATES NON-ZONAL}

We have now passed somewhat hastily in review the salient facts relating to geologic climates as interpreted by and through fossil floras. This has been supplemented and confirmed in many cases by an appeal to the pronouncement of fossil faunas. It is perhaps not too much to say that it has now been demonstrated beyond reasonable question that climatic zoning such as we have had since the beginning of the Pleistocene did not obtain in the geologic ages prior to the Pleistocene. I think this statement of conditions is very generally accepted by geologists and paleon- 
tologists-in fact, I am at a loss to know how the data available can be otherwise interpreted.

Assuming, as we now seem justified in doing, that this cardinal fact has been established, the human mind is so constituted that it is not satisfied to stop at this point, but it must seek, if possible, an explanation of the cause or causes that gave rise to this marked difference between the pre-Pleistocene and subsequent climatic distribution. In other words, Why was there no climatic zoning in the age before the Pleistocene? There must be a reason, if we can but find it.

In seeking an answer to this question, I may confess that I have been led far afield-much farther, in fact, than I had originally intended to go. As present-day climatic differentiation is so dependent on atmospheric conditions and variations, there is no logical stop, in looking backward over the climatic conditions that have obtained in the successively older and older geologic ages, short of a consideration of the original atmosphere; and, having reached this point, logic urges a consideration of the earth on which it rested, perhaps including the origin of the earth itself. I hasten to add, however, that it is not my intention to venture a full discussion or analysis of these profound problems for two good and sufficient reasons, not the least of which is lack of time.

The zonal distribution of climate as we know it today results from the direct, though variously modified, control by the sun. If the earth was without an atmosphere and had a homogeneous surface throughout, the distribution of heat would be strictly by latitude, producing what has been called solar climate. But the problem is by no means so simple, for solar climate is modified and delimited by a number of important factors, such as the presence of an atmosphere containing water vapor, carbon dioxide and other gases in varying amounts, together with dust particles from various sources. Solar climate is also further modified to a marked extent by certain physical features of the earth itself, such as continents, plateaus, mountains, deserts, oceans, etcetera.

It appears to have been a pretty general assumption, especially in late years, that the sun exercised approximately the same control over earth atmosphere, surface temperature, or climate in past geologic ages as it is known to do at present. If this is true it would be impossible to escape the conviction that climates should have been disposed in zones throughout the whole of geologic history - that is to say, this result would have followed inevitably and of necessity if the sun had dominated earth atmosphere as it now does; but, if the biologic criteria of the past have been correctly interpreted, the sun did not so dominate. Or, to be on the safe side, we should perhaps say that the sun's dominancy has, at 
most, not been continuous and uninterrupted, for on no other basis do certain observed facts seem explainable. For example, polar geniality of climate, such as occurred again and again in the ages before the Pleistocene, can not be explained on the basis of unmodified solar control. Glaciation such as that of the "Permo-Carboniferous," which occurred in and adjacent to the tropics, is impossible under a vertical or nearly vertical sun, or at least not without an elevation of the land-mass that is out of all proportion to the observed stratigraphic and structural data.

In other words, it seems evident that there must have been some other factor or factors that operated to obscure or modify solar control. Can these be predicated with any reasonable degree of certainty?

\section{CONSIDERATION OF THE ATMOSPHERE}

In seeking a possible answer we may first consider the atmosphere. It need hardly be recalled that the atmosphere, the outer gaseous envelope surrounding the earth, is a mechanical mixture of oxygen, nitrogen, a small increment of carbon dioxide, and still smaller quantities of various other gases, together with water vapor in amounts that vary with temperature, locality, and season. The height to which the atmosphere extends above the earth is not known, though it exceeds 100 miles, and onehalf the air is below the 20,000-foot level. According to Humphreys, ${ }^{25}$ "At an elevation that in middle latitude averages about 11 kilometers $[36,000$ feet] the temperature of the atmosphere becomes substantially constant, or, in general, ceases appreciably to decrease with increase of elevation; this is, therefore, the upper limit of distinct vertical convection and of cloud formation."

A beam of sunlight in passing from the earth to the sun has the rapidly vibrating light waves transformed in large part at the surface of the earth into slower vibrating heat waves. In passing from the outer limit of the atmosphere to the surface of the earth, the beam of sunlight is subject to certain losses of energy, such as absorption by the gases and vapors of the atmosphere, especially the water vapor bands, the "scattering of light toward the ground from the direct solar beam by the molecules and dust particles," and from the loss by scattering into space by these dust particles. Now as to the effect of the atmosphere itself: It is well known that the oxygen and nitrogen are transparent to both incoming light rays and outgoing heat rays, while the water vapor and carbon dioxide are largely opaque to the outgoing heat rays. This, then, is the crux of the whole matter. The water vapor in the atmosphere, aug-

${ }^{25} \mathrm{~W}$. J. Humphreys: Volcanic dust as a factor in the production of climatic change. Washington Acad. Scl. Jour., vol. 3, 1913, p. 367. 
mented by carbon dioxide, acts as a trap to imprison the heat rays, thus producing the so-called blanketing effect. Any increase or decrease in the efficiency of this thermal blanket may have very profound and farreaching results.

\section{POWER OF CLOUDS IN REFLEOTING THE SUN'S RAYS}

Some very recent observations (1918) were made by Dr. L. B. Aldrich, ${ }^{26}$ of the Astrophysical Observatory, on the power of clouds to reflect the rays of the sun. By means of a captive balloon he was able to secure readings from a pyranometer from the surface of a fog bank when the upper and lower surface of the fog lay respectively about 2,800 feet and 1,000 feet above the ground. He says:

"The measurements were singularly concordant and satisfactory, and gave as the mean reflecting power of the fog during the interval from 7 until 11 o'clock 78 per cent. No apparent change owing to the change of the height of the sun during that time was observed. However, it is hardly questionable that if the measurements had been made nearer sunrise the reflective power of the fog would been found somewhat greater. Accordingly, we must suppose that if there should be a planet completely covered with smooth clouds it would reflect upwards of 78 per cent of the solar rays otherwise available to heat its surface. In the case of the earth, the cloudiness is about 50 per cent, so that if the clouds were as smooth on this surface as the clouds observed, the result would be that they would reflect away about 39 per cent of the solar rays and make ineffective to warm the earth. Taking this result in connection with the consideration of the other parts of the earth's surface, it appears that the reflecting power of the earth as a whole for solar rays of all wave lengths should be in the neighborhood of 43 per cent."

The value of these observations is not to be underestimated. If the earth was surrounded by a complete cloud envelope through which only approximately 20 per cent of the sun's rays could penetrate and become available for heating the earth's surface, it can hardly be questioned that this source of heat is inadequate.

\section{SOURCES OF HEAT}

In general.-According to the late S. P. Langley, the earth, on the average, is still over 52 per cent cloud-covered, and this condition, be it recalled, is with the sun as the direct controlling factor in heating the earth's surface. It was long ago suggested that this cloud envelope, or thermal blanket, was much more extensive in the ages before the Pleistocene than it is now ; in fact, it is held that the cloud mantle was practically complete. Let us examine the data and see what warrant there is

${ }^{26}$ Smith. Misc. Collectlons, vol. 70, 1919, p. 28. 
for any such conclusion. As pointed out several times before, it must have followed that if the sun had dominated earth atmosphere throughout measurable geologic time to the extent it now does, temperatures would have been distributed by latitude; hence the solution hinges on the correctness of the biologic interpretation of a non-zonal arrangement prior to the Pleistocene. If this has been shown from trustworthy evidence admitting of no other conclusion-as indeed I believe it has-then, as Abbot has stated in a recent letter to me, "one must follow with the conclusion that the earth's heat supply in those times did not come principally (as now) from a source subtending a small solid angle."

It now follows that several solutions may be suggested. These have been formulated by Abbot as follows:

"1. The sun was shut off by clouds and the heat came from within the earth.

"(a) Internal heat persisted.

"(b) Radio-active heat was available.

"2. The sun was effectively bigger.

"(a) Sun then an extensive nebula.

"(b) Sun's rays reflected by extensive nebula."

Heat from a'bigger sun.-The second of these suggested solutions, namely, that which postulates an effectively larger sun, has had a number of advocates. For instance, it is given quite farorable consideration by Dr. Abbot in his well-known book on "The Sun," but he writes me that he does not now think so well of it as he formerly did.

The present sun is about 866,000 miles in diameter. It is giving up energy at a tremendous rate, which it is possible to measure with great accuracy. The manner in which the sun's heat is maintained is not certainly known, but the hypothesis that finds widest acceptance, that of Helmholtz, assumes it to be due to the gravitational infall of matter at its outer rim, by the transfer of motion into heat. It has been calculated that an infall of this kind of 250 feet per annum would be sufficient to maintain the present loss of energy. This, of course, implies that the sun must have had a definite beginning, just as it shows it to be tending toward an unmistakable end; in fact, Newcomb has calculated that at the present rate of loss of energy the sun, in seven million years, will be reduced to one-half its present size. Astronomers are not agreed as to the probable age of the sun, though, so far as I can learn, few of them incline to regard it as more than one hundred million years old, and many have hesitated to concede more than fifty million years to its existence. This is totally at variance with the demands recently made as to the age of the earth, for it is impossible to conceive of the earth as 
existing without the sun. Thus Barrell, in his most recent estimates, places the age of the earth at a minimum of seven hundred and fifty million years, with the possibility that it may be as much as one billion five hundred million years! Certainly there must be some readjustments or mutual concessions between astronomers and geologists before thest: widely discordant figures can be brought into harmony!

It is not only possible, but perhaps reasonable, to postulate a much larger, more diffuse sun during the earlier stages of its existence, perhaps a sun so large as to fill the orbit of the earth. With such a large-angle sun the rays would fall nearly vertical on perhaps a whole hemisphere at once. This would offer an explanation for an equable, non-zonal distribution of climate and would make possible the growth of tropical or subtropical vegetation within the polar circles. It would also provide an explanation for tropical or subtropical glaciation, given a sufficient elevation of the land-mass.

But it appears that there are certain astronomical objections that stand in the way of accepting this in its entirety. Just what they are I can not say, but I am informed by Dr. Abbot that he and Professor Moulton, of Chicago, went over the subject some years ago and reached the conclusion that "not more than double the life of the sun as a source of radiation capable of holding up the earth temperature could come that way under the most favorable assumptions."

Heat from the earth itself.-We may now turn to the other assumption, namely, a heat supply from the earth itself. The suggestion that the sun was shut off by clouds and the heat came from within the earth itself is, of course, not new; in fact, it follows as a natural corollary to one of the most prominent of the theories advanced to account for the origiv of the earth. It is the essential basis of the views advocated by Dr. Marsden Manson in his paper on the "Evolution of climates" and in numerous subsequent publications, though it may be added that it doe, not depend on the acceptance of the nebular hypothesis of earth origin.

Setting aside for the moment the discussion of primitive earth temperatures, we may consider the action that may reasonably be presumed to result under this hypothesis of a dual heat supply. Granted an initial surface temperature, from whatever source derived, that was higher than that now existing, it can not be doubted that a larger percentage of thr. water now existing in the seas, lakes, and rivers must then have existed in the form of vapor. As it ascended, this vapor would be condensed into clouds, forming a spheroidal cloud envelope surrounding the earth. It also seems certain that under this hypothesis the sun must have exerted 
substantially the same zonal action on the outside of this cloud spheroid that it now does upon the present cloud surface and, within the limits of certain modifying factors, upon the earth's surface. To quote from Hilgard, ${ }^{27}$ who has written in strong advocacy of this hypothesis:

“The tropical belt with its strong ascending currents, low barometer, and high temperatures; two adjoining arid belts with descending currents and high barometer, and the temperature zones to poleward, with variable but generally low barometer, would be defined on the cloud spheroid as they now are on the earth's surface, but with greater regularity, though perhaps less sharply defined."

A certain amount of earth heat, carried up by convection currents, is lost by radiation into space, but the solar radiation falling on the outside of the cloud spheroid would in part compensate for this loss, and thus the sun would actually become a conservator of earth heat without directly influencing the temperature of the earth's surface. This great amount of moisture in the atmosphere naturally led to greater and more rapid precipitation, and the rainfall was undoubtedly greater than at. present.

The further elaboration of Manson's hypothesis has been so graphically and succinctly stated by Hilgard that I venture to quote from his paper. He says:

"The isothermal spheroids or shells corresponding to our present temperatures would at first be at heights more considerable than at present; but as the heat carried up from the earth's surface was more and more lost by radiation into space from the exterior cloud-surface, the isothermal shells would gradually descend, and the temperature of the falling rains would become lower, so as under favorable conditions to fall as snow. It is clear that snowfall might occur at any period of the earth's evolution on high mountain ranges or plateaus, and there the accumulations of snow might at any period have formed nevees and glaciers with their well-known effects. . . . Owing to the higher radiating power of the earth-surface as compared with the ocean. as well as its much lower specific heat, the earth must have cooled more rapidly than the oceans by radiation alone. In addition to this, the water flowing from it into the seas would carry off a large amount of heat. Even while the ocean still received heat from its bed, the land areas would be a cooling agency especially for the ocean depths, while the warm oceanic surface waters would be supplying abundant vapor for precipitation on the relatively cooler land areas. The latter would finally fall to so low a temperature as to receive their precipitation in the form of snow, thus inaugurating the glacial period, during which the isothermal shell of, say, the freezing point of water, and below, descended near to the earth's surface. As the ocean also gradually cooled and evaporation diminished, the protecting cloud-envelope became thinner, first in the tropics and its flanking belts of lesser rainfall (which

${ }^{27}$ E. W. Hilgard. 


\section{F. H. KNOWLTON-EVOLUTION OF GEOLOGIC CLIMATES}

later became the arid belts); and thus gradually the zonal solar regime was established."

These are the essential features of Manson's theory and, whatever its fate may be, I thoroughly agree with Hilgard that it must be given very serious consideration. Of course, objection has been raised against the acceptance of this hypothesis of a higher initial and subsequent diminution of surface temperatures. We are told, for instance, that, owing to the law of conductivity of the rocks, the transmission of earth heat to the surface must have ceased as a practical factor very soon after the formation of an earth crust. We know, or think we know, that there is ample heat in the earth's interior, for if the ratio holds good of an increase of one degree for about 60 feet of depth, we shall have the stupendous temperature of $348,000^{\circ} \mathrm{F}$. at the center. But conduction is not the only means by which earth heat may be brought to the surface. Faults, fractures, denudation, thermal waters, orogenesis, and, of course, vulcanism are continually liberating appreciable amounts of heat. On the basis of vulcanism--if this is a really competent criterion-the earth appears to have been cooling since earlier geologic time; for, though by no means extinguished, vulcanic activity is much less evident now than it has obviously been in the past.

Radioactive heat.-But, fortunately or otherwise, we are not dependent for a possible solution of this problem on an original earth heat, whether developed from a cooling nebula or by impact and pressure of separate solid increments. The recent wonderful discovery of radioactivity introduces a wholly new and unsuspected set of factors; but the facts are so newly available that the possibilities and limitations are not yet fully worked out. It is now known that uranium and thorium, elements having the highest atomic weights known, are the parents of a series of radioactive elements. Each of these elements breaks down into a descendant series by giving off positively charged atoms of helium at an enormous velocity, by negatively charged electrons, also with high velocity, and by certain rays of the nature of Röntgen or X-rays. After a very long but measurable length of time a stable element is the result, as, for instance, lead, which results from the breaking down of uranium. This process is necessarily accompanied by the evolution of heat; in fact, as Barrell ${ }^{28}$ has said:

"It has been found that radioactivity gives such an embarrassingiy large quantity of heat that it has been necessary to assume the restriction of uranium and thorium with their observed percentages to the outer 40 miles

28 Joseph Barrell : Rhythms and measurements of geologic time. Bull. Geol. Soc. Am., vol, 28, 1917, p. 839. 
of the earth's crust, since otherwise the earth would be heating up with geological rapidity, instead of being a body slowly cooling or in thermal equilibrium."

It is not known to what depth in the earth the various radioactive minerals extend, nor is it known what effect great pressure may have on radio emanations; but inasmuch as these elements have the highest atomic weights known, it would seem a fair presumption that there is a progressively greater condensation of them toward the center. In any event, it is obvious that the restriction of these radioactive elements to the outer 40 miles of the earth's crust is a mere convention, devised for the sole purpose of getting around what might otherwise be an awkward condition of being obliged to account for too much heat. It wouli seem to me that it is within the bounds of possibility that this may be the key to an explanation of an augmented earth heat during the earlier geologic ages. As it seems now to have been demonstrated with more than a reasonable degree of certainty that the breaking down of the radioactive elements into a descendant series, with the consequent evolution of heat, is a process that requires a measurable, albeit a very long, period of time, it may be that this is the explanation of a higher earth heat during the earlier ages, and that it reached its maximum long prior to the Pleistocene, since which time it has been declining. This offers an explanation of the present cooling globe or one in approximate thermal equilibrium. But this is pure speculation, as difficult to prove as to disprove. However, in the next paragraphs certain facts will be set forth that seem to call for a higher inherent earth heat than we have had since the beginning of the Pleistocene.

\section{OCEAN TEMPERATURES}

A word may be said at this point in regard to the temperature of the ocean waters during early geologic time. It now seems to be settled beyond serious question that the waters of the early oceans were warm-in fact, that they were not permanently cooled as they are now until the approach of Pleistocene time. This does not necessarily mean that there may not have been some fluctuation in their temperature from time to time, for there doubtless was; but, taken by and large, the oceans were warm from the equator to the poles. On this point Ulrich ${ }^{29}$ says:

"Taking the geological marine record, as preserved in the fossiliferous rocks from the Cambrian to the Tertiary, it suggests equable, mild, almost subtropical climates over the whole Northern Hemisphere in all the ages represented."

${ }^{20}$ E. O. Uirich : Revision of the Paleozolc systems. Bull. Geol. Soc. Am., vol, 22, 1911, p. 352 . 
Ulrich also adds that there is undoubted evidence, notably in the eariy Cambrian and early in the Pennsylvanian, when "frigid conditions occurred at least locally." This is the very crux of the matter, for it seems clear that while there are undoubted evidences of glaciation, they were, at least for the most part, so very local in their effect that they seem to have made little impress on the temperature of the oceans, and hence on the continuity and distribution of marine life. As bearing on this point, Dr. John M. Clarke has expressed his opinion as follows:

"There is of course plenty of evidence of cold weather periods and also of local cold throughout Paleozoic history. I can not say that such determinations are, in any single particular within my knowledge, dependent upon the fossils of the rocks; nor can I say that the obvious evidences of recurrent land glaciation are connected in any way with or supported by any facts producible from coexistent faunas or floras. I have worked out with some particularity a somewhat circumscribed glaciation in the later stages of Devonian time. That it has had any effect on the marine faunas I can not say; whether It has affected the estuarine or river faunas represented by the Devonian fisthes, we can not tell because we are not able to deduce from their data the adaptations of those creatures."

The present average temperature of the surface of the oceans varies from about $-1.7^{\circ} \mathrm{C}$. at the poles to about $27.88^{\circ} \mathrm{C}$. in the warmest (Indian) ocean. The average surface temperature of the oceans as a whole is as follows: Atlantic, $16.9^{\circ} \mathrm{C}$; Pacific, $19.1^{\circ} \mathrm{C}$; Indian, $17^{\circ} \mathrm{C}$.

It is, of course, well known that water is a very poor heat conductor. According to Grabau, it has been calculated

"that a mass of water 5,000 meters deep, and of a uniform temperature of $0^{\circ} \mathrm{C}$, would, if in contact with a heat source of $30^{\circ} \mathrm{C}$. at the surface, experience the following rate of warming, providing no other factor, such as convection currents, etc., entered in. In 100 years no appreciable increase in temperature would be found at a depth of 100 meters; in 1,000 years not one per cent of the surface warmth is to be found at a depth of 300 meters, while it takes 10,000 years to carry this fraction of the surface warmth to a depth of 1,000 meters, and 1,000,000 years to carry it to a depth of 4,900 meters. After 1,000 years the temperature at a depth of 100 meters will be $7.3^{\circ} \mathrm{C}$., while at 200 meters it will be only $0.6^{\circ} \mathrm{C} .^{\prime \prime}$

In actual practice, however, the warming of a body of water is more rapid, due to the absorption of the sun's rays, vertical convection currents, and the sinking of heated saline waters whose density has been increased by the surface evaporation; but at best the process is a slow one. If, as has now been demonstrated, the process of heating up a great body of water is such a slow one, it must follow that it will give up its heat with an approximate degree of slowness. Now, the very pertinent 
question presents itself: What was the source or sources of heat that kept the oceans of the globe so continuously warm during all or most of early geologic time? According to H. F. Reid, ${ }^{30}$ the earth's surface at the present time receives from the sun at least 2,000 times as much heat as from the interior of the earth itself; yet, covering the period including the Pleistocene and subsequent time, during which at least the sun is admitted by all to have dominated earth temperatures, the heat supplied from this source has not been sufficient to remove the polar ice-caps or raise the surface temperature of polar waters even to $0^{\circ} \mathrm{C}$., though it is to be acknowledged that in many areas-perhaps everywhere-the remaining ice-covering is being very slowly reduced.

In seeking a solution of this problem of source of supply of heat, let us assume for the moment that it came from the sun and see what reasonable conclusions can be reached on this basis. In the first place, the whole matter is seemingly thrown out of court, as many times pointed out in this paper, on the ground that if the sun had been the principal source of heat in pre-Pleistocene time, terrestrial temperatures would of necessity have been disposed in zones, whereas the whole trend of this paper has been the presentation of proof that these temperatures were distinctly non-zonal. Therefore it seems to follow that the sun-at least the present small-angle sun-could not have been the sole or even the principal source of heat that warmed the early oceans.

Assuming again, for the sake of argument, that the conclusion regarding the non-zonal disposition of temperatures was in error, and that the heat for warming the early oceans actually did come from the sun, then it must have been from a hotter, small-angle sun or from a diffuse, largeangle sun. In either case the first effect would be an increase in surface temperatures, which would increase evaporation and thus make the cloud envelope more complete and efficient; and this in turn would automatically, though perhaps intermittently, shut off the sun's rays from access to the earth's surface. Considering the extreme slowness of the absorption of heat by water and the great amount that must have been necessary to heat up and maintain the warmth of the oceans, it becomes increasingly difficult - not to say impossible - to believe that it could have been supplied by the sun under the conditions predicated.

\section{EVIDENCES OF GLACIATION}

By many it is thought that one of the strongest arguments against a gradually cooling globe and a humid, non-zonally disposed climate in the ages before the Pleistocene is the discovery of evidences of glacial action

so Sclence, new ser., vol. 29, 1909, p. 29. 
practically throughout the entire geologic column. Hardly less than a dozen of these are now known, ranging in age from Huronian to Eocene. It seems to be a very general assumption by those who hold this view that these evidences of glacial activities are to be classed as ice ages, largely comparable in effect and extent to the Pleistocene refrigeration, but as a matter of fact only three are apparently of a magnitude to warrant such designation. These are the Huronian glaciation, that of the "PermoCarboniferous," and that of the Pleistocene. The others, so far as available data go, appear to be explainable as more or less local manifestations that had no widespread effect on, for instance, ocean temperatures, distribution of life, etcetera. They might well have been of the type of ordinary mountain glaciers, due entirely to local elevation and precipitation, of which we have many examples now existing. And in this connection it may not be out of place to* call attention to the difficulty of accurately fixing in the time scale these often widely scattered areas exhibiting glacial phenomena. It seems to me not only possible, but entirely probable, that there is a considerable element of error in the determination of the stratigraphic position and assumed or implied synchroneity of certain of these ancient glaciated areas. They are often unaccompanied by fossil remains, and hence their position can only be fixed within very broad limits.

\section{PHYSIOLOGIOAL ACTION OF INCREASED CLOUDINESB ON PLANT LIFE}

As already abundantly set forth in preceding pages, the conclusion seems inevitable, if the data has been correctly interpreted, that there was increased cloud production during the early geologic ages which shut out access of the sun to the earth's surface. As the question is almost certain to be raised as to the probable physiological effect of this clour mantle on plant life, I have taken occasion to ascertain recent observations and opinion on this point. Inasmuch as a very considerable percentage of existing plants grow under conditions where they seem to demand, or at least tolerate, strong sunlight, it has seemed to many a fair inference that similar condition must have applied to the earlier floras - that is to say, that their presence is proof positive of the presence of full sunshine-but the facts now available do not bear out this contention.

In this connection.I consulted with Dr. John M. Coulter, of the University of Chicago, and through him with Dr. William Crocker, of the same institution. Among other things, Dr. Crocker states:

"Late work is indicating very strongly that the main effect that light has on the development of the plant is its effect on photosynthesis and through 
the food thus manufactured on the rate and course of development of the plant."

Dr. Crocker also directed my attention to an important paper by Messrs. Brown and Escombe, ${ }^{31}$ in which they record results of the effect of varying amounts of light on photosynthesis. This work was carried on at Kew, England, where so-called full sunlight is not very full, owing to prevalent cloudiness. They say :

"When a leaf is exposed to full sunshine the radiant energy which is utilized for the photosynthetic process represents only a very small part of the total incident radiation. If we restrict the term "economic coefficient" to the ratio of these two values, the full radiation falling on the leaf being taken as 100 , it is evident that the leaf is an extremely wasteful transformer of energy, since it receives a very large amount of superfluous energy which does not contribute to the main function of the leaf. That the photosynthetic rays, even in sunlight of very moderate intensity, are in excess of the power of the leaf to utilize them has been shown by the experiments described in Part 2, $\mathrm{XXXX}$. It was found, for instance, where solar radiation of an average intensity of about 0.5 calorie per square centimeter per minute was reduced to about one-third of this intensity by passing through a thin canvas screen, forming an artificial 'cloud,' that it still contained an excess of photosynthetic rays over and above what was necessary to produce maximal assimilation in ordinary air ; for by means of the revolving-sector method the intensity of the radiation could be still turther reduced to one-quarter-that is to say, to one-twelfth of the original amount-before there was any sensible diminution of the assimilatory power of a leaf submitted to its influence."

It remains to ascertain the amount of light that would be available for photosynthetic processes under conditions of a complete and permanently overcast sky. These data are supplied in a paper recently published by Dr. H. H. Kimball, ${ }^{32}$ of the U. S. Weather Bureau. He says:

"Photometric measurements made at Mount Weather, Virginia, show that with a clear sky the total illumination on a horizontal surface varied from 10,000 foot-candles in June to 3,600 foot-candles in January. . . . The illumination on a horizontal surface from a completely overcast sky may be half as great as the total illumination with a clear sky, and is frequently one-third as great. On the other hand, during severe thunder-storms at noon in mid summer, the illumination may be reduced to less than one per cent of the illumination with a clear sky."

These results indicate that the supply of light would undoubtedly ba ample for plant needs, even with a complete cloud mantle. Although

\footnotetext{
31 H. T. Brown and F. Escombe : Researches on some of the physlologlcal processes of green leaves, with special reference to the interchange of energy between the leaf and its surroundings. Proc. Roy. Soc. Iondon, Series B, vol. 76, 1905, p. 86.

8 H. H. Kimball : Photometric measurements of daylight illumination on a horizontal surface at Mount Weather, Va. Monthly Weather Revlew, vol. 42, 1904, p. 652.
} 
plants now seem to tolerate strong sunlight, it is possible, even probable, that through exposure to strong light they have come to be greater lightdemanders. The ones grown under the postulated cloud conditions of the earlier geologic ages may have corresponded more nearly to our present shade-tolerant forms.

In the living flora the ferns hold a subordinate position, though there are perhaps as many specific types now as there were at any time in the past. The living ferns are preeminently shade-loving plants; in fact, few of them can long survive exposure to strong sunlight. Is it not possible that their shade-loving habit is a direct inheritance from the early geologic ages, when they were developed under a practically continuous cloud mantle? Ferns have now essentially the same structure, method of reproduction, and ecological requirements that they had throughout the Paleozoic and Mesozoic. If the ferns of the earlier ages were developed under conditions of strong sunlight, they have completely changed their habit without this fact being reflected in the structure.

\section{OBSTACLES TO THE ACOEPTANCE OF EARTH HEAT}

Other supposedly serious obstacles to the acceptance of this hypothesis have recently been formulated by Barrell..$^{33}$ He holds that "the amount of radioactivity known to exist in the crust appears to be adequate, or more than adequate, to account for the whole emanation of heat," but his deduction from this, namely, that "there is no evidence, therefore, that the earth is cooling and that the crust gave forth more heat in earlier times," does not seem clear. Under the present system of solar control, there may be a compensatory adjustment of heat derived from the two sources (earth and sun) that was lacking when the sun was not the dominant factor it now is. To my mind, logic supports the contention of a cooling globe during the major part of geologic history.

Barrell's second point-namely, that the deeper parts of many preCambrian formations, such as the Unkar and Chuar, exposed in the depths of the Grand Canyon section, do not show regional metamorphism, and hence that the "temperature gradient since the late pre-Cambrian could not, therefore, have been notably higher than at present"-appears to be based on the supposition that the entire section of perhaps 20,000 feet was buried and remained at a great depth for ages, while as a matter of fact it probably came to the surface in late Algonkian time and remained at or near the surface for a very long time, as shown by the

33 Joseph Barrell : Rhythms and the measurement of geologic time. Bull. Geol. Soc. Am., vol. 28, 1917, pp. 901, 902. 
fact that there is very little Cambrian, no Ordovician, Silurian, or Devonian, and comparatively little Pennsylvanian in this section.

While the above may be a satisfactory explanation of the specific case cited,-it may not explain lack of regional metamorphism in general. This point is touched on by Manson ${ }^{34}$ in his recently published paper, his statement reading as follows:

"The conductivity of the crust of the earth is so low that the heat which could be made available as a climatic factor through this process [liberation of earth heat] is negligible, except for very short periods over very limited areas. This extremely low conductivity was one of the highly conservative factors imposing the long duration of this source and its liberation is recorded in the altered and unaltered sedimentations and severe crustal ruptures up to the present era."

This interpretation means that earth heat, given off very slowly owing to the low conductivity of the rock crust, was stored in warm oceans. The warm waters increased evaporation and cloud formation, thus conserving the heat, which process was also aided by the sun's rays falling on the outside of the more perfect cloud spheroid. This slow trans. mission of heat through the rock crust has not only acted as a conservator of earth heat, but explains why rocks brought from great depths show so little evidence of having been subjected to great heat.

His third contention is that the "quantity of heat which the eart' delivers to the atmosphere is now, and must always have been, inconsequential in comparison with that derived at present from the sun"; hence, for example, "to have conducted five times the heat, the temperature gradient would have to be five times as steep, giving a temperature of molten rocks at a depth of five miles."

This ignores wholly the value of radioactivity, and in another part of the same paper (p. 839) Barrell says: "The discovery of radioactivity cuts out all solid basis for calculating age [of the earth] from the flow of solar energy or the temperature gradient of the earth." No furthe" comment on this point seems necessary.

Barrell's fourth proposition is as follows:

"The presence of banding in certain argellites of early pre-Cambrian times in Norway and Canada, associated with ancient glacial deposits, is directly comparable with the annual banding in stratification in Pleistocene clays in those same regions, and testifies to the dependence of temperature in those times on solar radiation with an atmospheric condition which permitted the existence of winter."

st Marsden Manson: Geologic and present climates, 1919, p. 217. 
I submitted this statement to Dr. W. C. Alden, who writes me as follows:

"It seems like a far cry from banded pre-Cambrian argillites to solar radiation and seasonal temperatures, yet there may be a direct and logical relation. The reasoning may be correct, but I would hesitate to jump directly to the conclusion stated. There seems to be no doubt that variation in stream-flow due to variation in precipitation resulting from seasonal changes will produce lamination in fine sediments, but I doubt if all lamination is produced in this way. Any other recurring condition that affected precipitation (rainfall) and the load of sediment carried by the streams might produce such lamination.' The factor of recurrence at more or less regular intervals, however, strongly suggests seasonal recurrence. This might be without the occurrence of winter, meaning by winter a cold season such as we experience in the temperate zone and higher latitudes. . . . I am not sure the lamination of sediments associated with glacial deposits might not be produced under other conditions. It requires close analysis to eliminate alternative possibilities when one is considering what might have happened in pre-Cambrian times."

Dr. R. S. Bassler, with whom I have discussed this question, has expressed the opinion that the banding in the pre-Cambrian argillites may possibly be due to segregation from shales more or less homogeneous when originally deposited. As examples he cites the many banded shales-all unaccompanied by evidences of glaciation-in Ordovician, Silurian, and Devonian rocks. Dr. E. O. Ulrich, with whom I have also discussed the problem, doubts the efficiency of the segregation hypothesis and considers the banding as purely a question of sedimentation. $\mathrm{He}$ is of the opinion that there are so many factors influencing the deposition of fine sediments that it is unwise or unsafe to pin much faith to variation in stream-flow and consequent deposition as dependent on seasonal changes, especially at a time so remote as the early preCambrian.

In view of these conflicting opinions, it does not seem that this contention can be considered as much more than a possibility. It will have to be supported by more exact information before it can be accepted.

Barrell's fifth objection reads as follows:

"The abundance of carbon in the clays of early pre-Cambrian time suggests the presence of sunlight sufficient to carry forward photosynthesis in plants and therefore the absence of an extremely dense cloud envelope."

This is a generalization on a very insufficient and insecure basis; for while pure carbon or graphite may be produced by the metamorphosis of coal or other vegetable debris, it by no means follows that it was alwajs so produced, especially in the older rocks. Carbon is formed in meteorites in a purely inorganic manner, as by the decomposition of metall: 
carbides. Moreover, the carbon or graphite in the Laurentian rocks is so vast in quantity-more, Sir William Logan once said, than in any similar area of Carboniferous rocks in the world-that it would require for its production an incalculable mass of algæ, which were without woody substance, and hence low in carbonaceous matter. And, further, many plants, notably red and brown algæ, do not require sunlight for their assimilation processes; hence, if we should grant that the pre-Cambrian carbon had been reduced by plant life, it would by no means follow that this life process implied sunlight. It could have gone forward in absence of direct sunlight.

The last point Professor Barrell seeks to make is based on the fact that glacial conditions and, as he holds, periods of widespread aridity have recurred at intervals since Middle pre-Cambrian time; hence he concludes that the composition of the atmosphere and ranges of temperature have been subject to fluctuation through all geologic time.

The deductions based on glacial conditions apparently are on the supposition that all observed glacial activities are veritable ice ages having a profound effect on temperatures, life distribution, etcetera. The fallacy involved in this conception has already been set forth.

The criteria on which widespread aridity are predicated are not stated, though presumably based on the conventional doctrine of red beds, deposits of salt, etcetera. The great deposits of salt are presumed to have resulted from the evaporation of impounded saline waters. But has any one attempted to visualize the physical setting essential for the formation of a 100-400-foot bed of salt by evaporation? Is it certain that such deposits are proof positive of aridity?

The physical character of sediments and the interpretation of their mode of deposition has been used to prove aridity, but when-as, for example, in the case of the old Red sandstone-interpretations of the same data range all the way from the permanent deserts postulated by Walther and Goodchild and the semi-aridity advocated by Barrell and Jukes-Brown to the contention of a marine origin by Hugh Miller and recently confirmed by Macnair and Reid, the layman may well hesitat?.

There is undoubtedly an element of truth in all of these several contentions, but it is when they are forced to bear too great a burden that they falter. As Barrell ${ }^{35}$ has well said in another connection:

"In general, traditional criteria are liable to lead into error because they become accepted as axioms and are applied without further thought. They lag behind the development of a science."

s5 Joseph Barrell : Dominantly fluviatile origin under seasonal rainfall of the Old Red sandstone. Bull. Geol. Soc. Am., vol. 27, 1916, p. 354. 
REVIEW OF HYPOTHESES PROPOSED TO ACOOUNT FOR THE INITIATION OF GLAOIAL ACTIVITIES

In general.-The broader problems that we have been considering naturally include the several hypotheses that have been advanced from time to time to account for the origin of glaciation. Most of these hypotheses were proposed to account for the initiation of the great Pleistocene ice age; but, as the evidence gradually accumulated and it became evident that there had been numerous other refrigerations, the burden forced on these hypotheses of explaining all glaciations became too heavy, and one after another they appear to have failed of adequacy. I have ventured to review several of the more prominent of these proposals and to point out where and why they seem to fail.

Shifting the position of the poles.-In order to account for the presence of tropical vegetation within the polar circles and of glaciation in middle latitudes, it was perhaps natural and seemingly logical to postulate a wandering of the earth's axis of rotation within its body-a shifting of the poles. This hypothesis was advanced nearly a century ago, and for a time found many advocates among geologists, and more especially among biologists, to whom it furnished an easy explanation of certain puzzling facts of distribution among plants and animals. They failed to appreciate, or indeed to perceive, that this shifting of the earth's axis is "really a problem of mathematics, as much as are the movements of precession and orbital perturbations." Hence astronomers and mathematicians have in general been opposed to hypotheses of polar migration, and Lord Kelvin, and more especially George H. Darwin, have apparently set the matter definitely at rest. Beyond a very slight possible movement, involving at the outside not more than 10 degrees, that may have taken place in the geographic position which the axis held at the consolidation of the earth, they conclude that polar migration is mechanically impossible.

Barrell has recently published an elucidating review of the "Status of hypotheses of polar wanderings," 36 which he concludes as follows:

"It would appear that the assumption of polar wandering as a cause of climatic change and organic migrations is as gratuitous as an assumption of a changing earth orbit in defiance of the laws of celestial mechanics. Unless some wholly unsuspected forces are at work within the centrosphere, polar wandering has no more basis in science than Symmes's imaginings of a hollow earth. From all that is known at present the doctrine must be regarded as a vagrant speculation, not a working hypothesis."

so Joseph Barrell : Science, n. s., vol. 40, Sept. 4, 1914, pp. 333-340. 
Continental elevation hypothesis.-It is probable that, all things considered, there is a wider acceptance among geologists and others of the postulate that changes in temperature due to continental elevation are sufficient to account for the inauguration and control of glaciation than any other of the many hypotheses that are up for discussion. As Gregory says, it is attractive from its simplicity. It is of course well established that there was a measure of continental elevation and subsequent depression during, for instance, the Pleistocene invasion. This is proved by the prolongation of fjords and land valleys on the adjoining ocean floor, by the finding of littoral shells in submerged areas, and of marine organisms on lands now elevated, though in some cases the last-mentioned occurrence may have resulted from an ice-mass that filled and plowed out a shallow sea basin, thus pushing them onto and over the adjacent land. But whether the hypothesis of continental elevation is fully competent to account for the origin and control of glaciation at all times and in all places, and under the usual postulate of a solar control similar to that now obtaining, is much to be doubted.

In discussing the several advances and retreats of the Pleistocene icesheets, Ulrich ${ }^{37}$ says :

"Assuming that elevation is competent to bring about glacial conditions in areas of abundant precipitation, it seems to me that the subsequent melting and retreat of the ice-cap may be due chiefly to the subsidence of the areas, and that the subsidence resulted from overloading. In other words, that the isostatic equilibrium had been disturbed by loading, and that subsidence set in when the ice attained a certain limit of thickness. . . . Reaching the level of melting, the ice-cap was gradually removed, only to be rebullt when the direction of movement was first stopped and then reversed."

Coleman, ${ }^{38}$ in considering this problem of Pleistocene elevation, reaches a quite different conclusion. He says :

"Local elevations of thousands of feet can hardly be conceived as taking place at the same time over most of North America, the whole length of the Andes and Patagonia, all northern Europe, the Alps, the mountains of Turkestan, the Himalayas and Altai Mountains, the Atlas region, Rewenzori, Kenai, and Kilimanjaro, the New Zealand Alps, and Kosciusko in Australia, not to mention other localities glaciated in Pleistocene times. The theory breaks down of -its own weight."

Coleman also adds that in some cases elevation is actually hostile to the formation of ice-sheets, as witness the observations of Scott, that on the

gr E. O. Ulrich : Revision of the Paleozoic systems. Bull. Geol. Soc. Am., vol. 22. 1911 , p. 353.

${ }^{38}$ A. P. Coleman : Glacial periods and their bearing on geological theories. Bull. Geol. Soc. Am., vol. 19, 1908, p. 363. 
Antarctic table-land, 9,000 feet above sealevel, the ice is dwindling and the glaciers retreating. In this area, at least, depression might extend glaciation by increasing precipitation.

If it were worth while, an indefinite number of quotations both for and against this elevation hypothesis could be made; but out of this wealth of more or less conflicting testimony, it seems to me there must come the conviction that it may nevertheless have played a relatively important, though not always the major, rôle in the production of glaciation. We know that even under the present system of solar control of temperatures, if there is given the requisite elevation and adequate precipitation, accumulation of snow and ice will result. It might even be possible on this basis to explain a majority of the evidences of glaciation that have been described from the earlier rocks; for, as already mentioned, they are or may be of the well known mountain type of glaciation. But it seems to me improbable, not to say impossible, with the atmosphere controlled by the sun, for elevation alone to account for the inauguration of the three major periods of glacial activity. The Pleistocene glaciation was most extensive in North America. It was laid down over a broad, fairly level plain, and to my mind there is no convincing evidence of a continental elevation that seems adequate to account for its initiation. Still less does it seem competent to account for the "Permo-Carboniferous" glaciation. As has been shown, however, even a moderate elevation coupled with non-solar control seems fully competent to explain all types of glaciation.

Changes in atmospheric circulation hypothesis.-This explanation, which was especially advocated by Harmer ${ }^{39}$ as applied to the Pleistocene climate of northwestern Europe, is conditioned on changes in atmospheric circulation resulting from geographic changes such as variation in continental outline and elevation. It is, of course, well known that quite marked meteorological phenomena are dependent on or influenced by terrestrial configuration, but this hypothesis fails utterly to explain the initiation of the equatorial "Permo-Carboniferous" glaciation, or of tropical or semitropical temperatures in polar lands. Moreover, atmospheric circulation, as here made use of, is of necessity based on the assumption, not considered tenable by the writer, that the sun has controlled earth atmosphere throughout the whole of geologic time as it does now. That this was a minor contributing factor during Pleistocene and subsequent time is possible, but it could hardly have been more than this when we reach the points at which the glaciation took place-some on mountains,

5. W. Harmer : Jour. Geol. Soc., vol. 57, 1898, pp. 405-472. 
others on broad, low plains; some on small oceanic islands, others along seacoasts or on isolated mountains in the middle of a great continent.

Hypothesis of, the variation in the atmospheric content of carbondioxide.-The general proposition that a change in the amount of carbondioxide in the atmosphere might be sufficient to initiate glaciation was suggested by Tyndall more than half a century ago, and in recent years it has received able advocacy by Arrhenius and by Professor Chamberlin. The present normal content of the atmosphere is about .03 per cent. According to calculations by Arrhenius, an increase of carbon-dioxido to .09 per cent would be sufficient to raise the temperature in the polar regions by from $12^{\circ}$ to $16^{\circ} \mathrm{F}$., giving a temperate climate, while a decrease by about one-half of the present amount would be sufficient to bring about a period of glaciation similar to that of the Pleistocene.

The slight changes required are so very modest in amount that it must be confessed this constitutes a very attractive hypothesis, especially after one has followed Professor Chamberlin's exposition; but when it is critically examined a number of objections obtrude that seem to remove it from the category of major factors in the initiation of glaciation or deglaciation. What seems to me to be a most formidable objection is the rapid and repeated fluctuations of the carbon-dioxide content of the atmosphere that must be postulated to account for the retreat and readvance of glacial activity during the Pleistocene ice age, to say nothing of those of other geologic times. "Surely," as Edgeworth David ${ }^{40}$ has said, "there is hardly scope here for a world-wide variation of carbondioxide in the earth's atmosphere repeating itself so frequently over such short intervals of time." That is to say, that why there should have been this intermittent activity, separated by millions of years in the earlier ages, and the sudden fluctuations in the Pleistocene, separated at most by a few thousands of years, is not apparent; also, it should not be forgotten that according to Schloesing, ${ }^{\mathbf{1 1}}$ and supported by Dittmar, the ocean exercises a powerful and potent control over the amount of carbon-dioxide in the atmosphere. The manner of this action and reaction is set forth by Gregory ${ }^{42}$ as follows:

"If the amount of carbonic acid in the atmosphere is diminished, the bicarbonates in the sea are dissociated; the gas thus liberated is thus poured into the air, until the former equilibrium between the tension of the carbonic acid

40 T. W. Edgeworth David: Conditions of climate at different geological epochs. Cong. géol. Internat., Compt. rend., Tenth Session, 1906 [1907], p. 477.

41_ Schloesing: Sur le Constance de la Proportion d'acide carbonique dans l'air. Compt. Rend., vol. 90, 1880, p. 140.

${ }^{42}$ J. W. Gregory : Climatic rariations, their extent and causes. Cong. géol. internat., Compt. rend., Tenth Session, 1906 [1907], p. 419. 


\section{F. H. KNOWLTON-EVOLUTION OF GEOLOGIC CLIMATES}

in the atmosphere and in the sea is reestablished. Hence a reduction of carbonic acid in the air is automatically followed by the discharge of nearly as large a quantity from the sea, so that any reduction is distributed between the air and the ocean. Any increase of carbonic acid in the atmosphere is followed by a reverse change, and only one-sixth of the amount poured into the atmosphere is retained there. It is true that great variations in the relative extent of sea and land would affect the dissociation pressure of the bicarbonates in the sea; but it would require a great reduction in the area of the sea surface to affect the equilibrium appreciably."

Again, it is to be pointed out that there is a non-coincidence of date. for periods of glacial activities. In accordance with the well-known law of diffusion of gases, any variation of the carbon-dioxide content of the atmosphere should affect the temperature of the whole world simultaneously, although, as shown by Arrhenius, it need not be the same in all latitudes; but it might be expected that corresponding latitudes in the hemispheres would exhibit practically the same effects. But the facts of historical geology do not altogether substantiate this supposition. Another weighty objection is offered by the fact that certain conditions that might have been expected to influence the variation of carbondioxide in the atmosphere have not been followed by the glacial activity the theory would call for. For instance, those periods of active con. sumption of carbon-dioxide, as marked by the formation of great limestone deposits, must have been supplied from the atmosphere. Among the greatest limestone-producing periods are the Mississippian, Jurassic, Cretaceous, and Eocene; yet none of these was followed by glacial manifestations. The Miocene and Pliocene, which were followed by pronounced glaciation, have far less of known limestone or coal accumulation than the Pennsylvanian or Cretaceous, both of which are without glacial activities.

Periods of intensive vulcanism, such as occurred in the Devonian, the Permian, the Upper Cretaceous, the Eocene, and the Oligocene, were not followed by marked glacial activity; yet the "Permo-Carboniferous" and Pleistocene glacial epochs were preceded by vulcanism.

The conclusion, therefore, seems to me unavoidable that the hypothesis postulated on an increase or decrease of the amount of carbon-dioxide in the atmosphere can not be regarded as a major factor in controlling glaciation. That it may have at times been a minor contributing factor is not only possible but quite probable.

Transportation theory.-In attempting to account for the presence of the great variety of plant remains now found in Arctic and sub-Arctic regions, it has been boldly asserted by some writers that they have bee:- 
drifted by marine currents to the places where they now are. It is of course well known that seeds and fruits of various kinds may be transported vast distances by ocean currents, and deep dredging by Agassiz and others off the American coasts has disclosed the presence on the ser bottom of plant debris, such as wood, branches, leaves, and seeds in various stages of decay. In some instances these remains were fairly abundant at a distance of 1,100 to 1,200 kilometers from shore, which corresponds to about 10 degrees of latitude.

But the plants in the Arctic regions fall within a quite different category, as they exhibit unmistakable evidence of having been deposited in fresh water. Nathorst ${ }^{43}$ has recently published a paper in which he describes fully the depositional conditions under which the plants were entombed. The deposits range in age from Devonian to Eocene, and the plants occur often in shales overlying coal and are often underlain by clays filled with rootlets and into which the plants, roots, and stems, penetrate. There is little or no evidence of sorting by water, there often being branches, leaves of various sizes, and fruits, evidently from the same tree, all being in frequent association with Unios and other fresh-water shells. The matter may be considered as settled, that whatever the explanation of the climatic conditions which permitted their growth, full account must be taken of the fact that they undoubtedly grew at or very near the places where they are now buried.

Reversal of deep-sea circulation.-Some years ago Prof. T. C. Chamberlin ${ }^{44}$ advanced a proposition, later strongly indorsed by Willis, ${ }^{45}$ that the present deep-seated equatorward circulation of cold oceanic waters is abnormal, and that the more normal condition is a poleward movement of warm, highly saline waters in the depths instead of at the surface. This hypothesis was advanced to explain in perhaps major part the polar geniality of climate that geologic and paleontologic evidence shows conclusively to have occurred again and again in the ages before the Pleistocene. Under present conditions the density of polar waters is due primarily to cold, and this density may be increased by the forcing out of salts from the superficial layers by freezing; the absence of large rivers also contributes to the same end. If the polar cold could be ameliorated, obviously these influences would be moderated. Similarly, at the present time the waters in the equatorial regions are evaporated

\footnotetext{
4s A. G. Nathorst: Fossil floras of the Arctic regions as evidence of geological climate. Geol. Mag., new ser., vol. 8, 1911, pp. 217-225.

«T. C. Chamberiln: On a possible reversal of deep-sea circulation and its influence on geologie climates. Jour. Geology, vol. 14, 1906, pp. 363-372.

15 Bailey Willis : Science, new sc ., vol. 31, 1910, p. 245.
} 
and warmed and "rendered light because warm, yet heavy because saline." In the matter of actual density the equatorial waters are lighter than the polar waters, but the balance is very small, "and," says Willis, "were the polar waters less chilled or more freshened, or both, the equatorial waters would be heavier, and the reversed circulation suggested by Chamberlin must result."

As thus presented, it must be confessed that this hypothesis seems reasonable, and if it could be proved would be of weight in accounting for the presence of tropical or subtropical vegetation in polar lands; but it was reserved for Dr. E. O. Ulrich to point out its utter failure to explain the occurrence of the same marine faunas in the polar regions that are found in temperate and tropical zones. On this point Ulrich ${ }^{4:}$ says:

"In the first place these raunas, with very few exceptions, are all littoral or near-shore faunas, and their migration, whether in the oceanic or continental basins, are almost confined to the shore and bottom of the shallow seas in which they thrived. With organisms so sensitive as these to changes in temperature and depth, extensive migration under any but equable climate and bathymetric conditions would have been highly improbable, if not impossible. As corals and other animals that are now restricted to warm waters did so migrate, we must assume either that at such times mild climates prevailed or that in ages preceding the present these organisms were not affected by changes in temperature-a conclusion altogether repugnant to the geologist. Assuming that they were then as now as sensitive to temperature changes, their fossil occurrence in all latitudes must be accepted as proving at least occasional times of universally mild climates - that is, such conditions prevalled in at least the relatively brief geologic ages of which we have a marine sedimentary record in the boreal basins. . .

"Now, according to the theory of reversed circulation, warm waters sank in the equatorial zone and reappeared at the surface in the polar regions. Could they have carried the littoral warm-water faunas with them? Manifestly, no. Or, could these faunas have migrated in their usual manner along the shore? Again we must say no, since the hypothesis requires a southward movement. of cool superficial waters, which would have effectually barred shore migration." . . .

Ulrich finally concludes as follows:

"It becomes questionable then if reversal of oceanic circulation was ever an important factor in faunal distribution. Indeed, we may go further and doubt if actual reversals ever occurred."

If for the moment we accept this postulate of a reversal of oceanis circulation, what effect may it be presumed to have on plant distribution?

16 E. O. Ulrich : Revision of the Paleozole systems. Bull. Geol. Soc. Am., vol. 22, 1911, p. 354. 
It might to a certain extent facilitate the equatorward migration of floras that originated within polar circles, but would it not soon erect a cold, perhaps impassable barrier in middle latitudes? That is, if the waters were warmed in the equatorial region and sank to the bottom to emerge in polar areas, they would begin to flow equatorward, gradually losing heat until somewhere in middle latitudes, and before they again came under the warming influences of the equatorial region there would be a point of maximum cold. Thus as a bar to the free interchange of floras between opposite high latitudes, such as undoubtedly occurred, there would be erected three barriers, two cold areas in opposite middle latitudes, separated by a warm area in the equatorial region.

The ascertained facts of plant distribution will not tolerate any such interpretation, and therefore it is much to be doubted that such reversal did or could have taken place.

There is also another point that may be urged against this theory of reversed circulation. The terms of this hypothesis call for a heating area in the equatorial region, and this in turn implies a solar control of terrestrial temperatures similar to that now obtaining. As alread; pointed out again and again, this could only result in a zonal distribution of temperatures which would seemingly nullify the ameliorating effect that might be brought about by warm waters rising within the polar circles.

Volcanic dust as a climatic factor.-Benjamin Franklin was one of the first, perhaps the first, to call attention to the possibility of volcanic dust as a factor in the production of climatic changes. It seems that during the summer of 1783 there was a constant fog over all of Europe and most of North America, and the winter of 1783-84 was unusually severe. He noted that Hecla, in Iceland, and adjacent volcanoes were in active eruption, and suggested this as a possible cause of the cloudiness and hence of the lowered temperature.

It is only in recent years, however, that accurate observational data have been available on which to base a dependable conclusion as to the possible effect of volcanic dust particles in the upper air in shutting off the sun's rays. W. J. Humphreys ${ }^{47}$ especially has published several papers on this subject. It is now possible to measure the size of volcanic dust particles with reasonable accuracy and to determine their time of fall. He states that in middle latitudes the temperature of the atmosphere becomes substantially constant at an average elevation of about 1

17 W. J. Humphreys : Volcanic dust as a factor in the production of climatic changes. Washington Acad. Scl. Jour., vol. 3, 1913, pp. 365-371. 
kilometers $(36,000$ feet). "This is, therefore, the upper limit of distinct vertical convection and of cloud formation."

All dust, from whatever source, is quickly washed out of the lower or cloud region by rain or snow, but such as may happen to reach the upper or isothermal region of the atmosphere continues to drift there until it is brought down by gravity to the level of passing storms. In accordance with recently made measurements on the terminal velocity of falling globules, it appears that it may take from one to four or more years before these dust particles return to the earth. In the meantime they drift out from whatever source into a thin veil, "covering perhaps the entire earth."

With these data it is possible to calculate the comparative action oi volcanic dust on terrestrial and on solar radiations. According to Humphreys, it is "roughly thirtyfold more effective in shutting solar radiation out than it is in holding terrestrial radiation in. Therefore, a veil of volcanic dust must produce in inverse greenhouse effect, and, if long continued, should perceptibly lower an average temperature." HC concludes as follows :

\footnotetext{
"From the above it appears quite certain that volcanic dust can lower the average temperature of the earth by an amount that depends on the quantity and duration of the dust, and that it repeatedly has lowered it certainly from $1^{\circ} \mathrm{F}$. to $2^{\circ} \mathrm{F}$. for periods of from a few months to fully three years."
}

Humphreys gives a list of the most noted volcanic eruptions from 1750 to 1912 , and, so far as can be gathered from the often meager historical data, each, with a single exception, was followed by a markedly cold period.

In the summer of 1912 Abbot and Fowle ${ }^{48}$ conducted a series of observations at Bassour, Algeria, and at Mount Wilson, California, on the effect on solar radiation of the volcanic dust believed to have been deriver from the eruption of Mount Katmai, Alaska, in the early part of June, 1912. The haziness due to this cause was first noted in Algeria on June 19 and at Mount Wilson on June 21, and continued for more than three months, when the observations terminated. These authors conclude that this veil of volcanic dust decreased the heat available to warm the earth by about 10 per cent of the solar constant of radiation. Ther write as follows:

"It might be expected that if so great a decrease as this should continue indefinitely, the mean temperature recorded at meteorological stations would

48 C. G. Abbot and F. F. Fowle: Volcanoes and climate. Smithsonian Misc. Coll., vol. 60 , no. 29, 1913, pp. 1-24. 
thereby be lowered by about $7^{\circ} \mathrm{C}$. But it is not certain that the effect of this considerable diminution of heat was not counteracted by some change in the average cloudiness, or in the nocturnal radiation of the earth to space. It is conceivable that the cloud of haze prevented the escape of radiation of the earth to space in the same manner that it prevented the incoming of radiation from the sun to the earth, so that the decrease of heat available to warm the earth may have been in part or in whole compensated by a decrease in the rate of escape of heat from the earth, owing to the presence of the haze."

Although further and perhaps more exact observational data may be required to determine accurately the several factors involved, it appears to have been demonstrated with a remarkable degree of certainty that the presence of a veil of volcanic dust in the higher atmosphere may have an appreciable effect in decreasing solar radiation, and hence in reducing the amount of the sun's heat that reaches the earth. From the historical record, which covers only about 150 years, it appears that practically all considerable volcanic eruptions have been followed by cold or cooler temperatures. It is therefore assumed that the action was similar is past geologic ages; but whether it is now or has ever been sufficient to initiate glaciation may well be doubted, though it may well enough have been a minor contributing factor.

\section{VIEWS OF BARRELL}

It appears to be the conviction of many geologists that the world-wide mild climates of earlier geologic ages, together with middle latitude glaciation, etcetera, may have resulted from the combination of a number of local factors rather than from a single compelling cause. For example, Barrell writes me as follows:

"I am inclined to think that a number of fundamental factors have been involved. The earth now has a very pronounced relief with high mountain ranges and lack of shallow seas. The high mountain ranges comb out the moisture from the air. Less moisture means cold continental climates. General coldness reduces evaporation and the smaller water area also results in less evaporation. In former ages a greater evaporation area and lesser mountains would result in far higher normal humidity for the whole earth. Rain would result from a greater degree of supersaturation; chiefly in higher latitudes, and its precipitation would tend to keep the temperature high by giving up the latent heat of the water vapor. Warm waters and cloudy skies would aid in giving a winter mildness of climate. We have that now prevailing in western Ireland, western Patagonia, and certain other regions with latitude over $50^{\circ}$. The mildness and moistness of climate permit in both of those very rainy regions extreme luxuriance of vegetation. To account for mild polar climates these conditions would have to be more wide-spread and reach $30^{\circ}$ farther from the equator. The results would be helped out by a perpetual 


\section{F. H. KNOWLTON-EVOLUTION OF GEOLOGIC CLIMATES}

cloud mantle through the winter over such high latitudes resulting from the air being colder than the water."

Barrell also thinks that the problem is made easier of solution if there can be found evidence of the truth of the reversal of deep oceanic circulation, but certain of the facts that seem to offer a fatal objection to this view have already been presented (page 559).

To return for a moment to the views expressed by Barrell: It is easy to believe that with a low land-mass and broad, shallow, epicontinental seas the temperature would be somewhat raised, thus inducing greater evaporation, greater cloud formation and rainfall, and in the end a milder, more equable climate; but it seems to me difficult to believe that this would be of sufficient importance and magnitude to account for the varied phenomena that must be explained, especially as it appears to be predicated on the currently accepted theory of solar control of earth temperatures. The equable moist climates of the regions cited, Ireland and Patagonia, must in part be due to topographic conditions and in part to ocean currents, and any attempt at a poleward extension of these conditions to cover the 30 degrees between these localities and the poles would seem to present insuperable difficulties, especially when we consider the vast eons of time that must be accounted for in the ages before the Pleistocene. Therefore, it seems to me highly improbable that the factors called into play could have been of sufficient magnitude to have caused and maintained polar geniality, such as happened again and again. Still less does it seem that they could account for sealevel glaciation in middle and equatorial latitudes such as that of the "Permo-Carboniferous."

\section{Summary and Conclustons}

Now we have come to the point where it is proper to ask what progress, if any, we can presume to have made toward a solution of the several problems connected with the study of geologic climates. The various hypotheses and theories have been passed in a more or less critical review, and it is believed that a certain amount of chaff has been cleared away, thus laying a possible foundation for an acceptable explanation; but probably it would be altogether too much to claim that any hypothesis has been so far advanced that it is likely to receive universal acceptance. Barrell, when confronted by a somewhat similar interrogation, states flatly that "the depths of geologic time leave us face to face with the unknown."

To my mind, however, the case does not seem quite so hopeless. The facts that have been presented regarding the warm oceans of much if not 
all of recorded pre-Pleistocene time seem to me to present a very strong presumptive case for a source of heat supplied by the earth itself. I am, of course, perfectly well aware that this view is counter to the pronouncement of the physicists and mathematicians, who are very emphatic in their opinion that the earth could never have supplied more than a small increment of the heat that is obviously called for. On the other hand, it seems to me absolutely impossible, from the data as presented in the foregoing pages, that the sun could have supplied the heat requisite to warm the early oceans. We are told that at the present time the sun supplies more than 2,000 times as much heat as is supplied by the earth itself; yet since Pleistocene time, when the present system of solar control is believed to have been established, it has not been able to warm the oceans as they were certainly warmed in pre-Pleistocene time. Furthermore, solar control is fatal to non-zonal climates, polar geniality, and tropical or subtropical glaciation. If the sun was the dominant factor in maintaining temperatures on the earth during all recorded geologic time, how or why did it fail in Pleistocene time? I can not escape the conviction that more weight must be attached to the contention that the earth itself has supplied a greater amount of heat than is now admitted to be possible. I do not see how the ascertained facts can otherwise be explained. Whether this heat came from the original earth heat, or from some augmented form of radioactivity, or from a combination of both sources, I am not prepared to say. If the mathematicians and physicists had always been right in their pronouncements on earth history, we might have more faith; but, to mention only one recent instance, after the experience in the fallibility of these arguments in determining the age of the earth, which has been so completely upset by the newly discovered factor of radioactivity, it is at least unwise or unsafe to put a too rigid. dependence on them. As Huxley once said:

"Mathematics may be compared to a mill of exquisite workmanship, which grinds you stuff of any degree of fineness; but nevertheless what you get out depends upon what you put in; and as the finest mill in the world will not extract wheat-flour from peascods, so pages of formulæ will not get a definite result out of loose data."

Therefore, it seems to me to be well within the limit of possibility that there may be factors in this problem of earth heat that are not properly evaluated or are unsuspected or undetected which may vitiate or modify previous results. 
Downloaded from gsabulletin.gsapubs.org on August 7, 2015 


\section{Geological Society of America Bulletin}

\section{Evolution of geologic climates}

F. H. KNOWLTON

Geological Society of America Bulletin 1919;30, no.

4;499-566

doi: $10.1130 / G S A B-30-499$

Email alerting services

Subscribe

Permission request click

www.gsapubs.org/cgi/alerts to receive free e-mail alerts when new articles cite this article

click

www.gsapubs.org/subscriptio ns/ to subscribe to Geological Society of America Bulletin

click

http://www.geosociety.org/pub s/copyrt.htm\#gsa to contact GSA

(C) 1919 Geological Society of America 
Copyright not claimed on content prepared wholly by U.S. government employees within scope of their employment. Individual scientists are hereby granted permission, without fees or further requests to GSA, to use a single figure, a single table, and/or a brief paragraph of text in subsequent works and to make unlimited copies of items in GSA's journals for noncommercial use in classrooms to further education and science. This file may not be posted to any Web site, but authors may post the abstracts only of their articles on their own or their organization's Web site providing the posting includes a reference to the article's full citation. GSA provides this and other forums for the presentation of diverse opinions and positions by scientists worldwide, regardless of their race, citizenship, gender, religion, or political viewpoint. Opinions presented in this publication do not reflect official positions of the Society.

\section{Notes}

(C) 1919 Geological Society of America 